\title{
Late Miocene - Recent exhumation of the central Himalaya and recycling in the foreland basin assessed by apatite fission-track thermochronology of Siwalik sediments, Nepal
}

\author{
Peter VAn der BeEK ${ }^{*}$, Xavier Robert, JeAn-Louis Mugnier, Matthias Bernet, \\ PASCALE HUYGHE AND ERIKA LABRIN \\ Laboratoire de Géodynamique des Chaînes Alpines, Université Joseph Fourier, BP 53, 38041 \\ Grenoble Cedex, France
}

Published in: Basin Research, v. 18, p. 413-434, 2006.

\begin{abstract}
Thermochronological analysis of detrital sediments derived from the erosion of mountain belts and contained in the sedimentary basins surrounding them allows reconstructing the long-term exhumation history of the sediment source areas. The effective closure temperature of the thermochronological system analysed determines the spatial and temporal resolution of the analysis through the duration of the lag time between closure of the system during exhumation and its deposition in the sedimentary basin. Here we report apatite fission-track (AFT) data from 31 detrital samples collected from Miocene to Pliocene stratigraphic sections of the Siwalik Group in western and central Nepal, as well as three samples from modern river sediments from the same area, that complement detrital zircon fission-track (ZFT) and $\mathrm{U}-\mathrm{Pb}$ data from the same samples presented in a companion paper. Samples from the upper part of the stratigraphic sections are unreset and retain a signal of source-area exhumation; they show spatial variations in source-area exhumation rates that are not picked up by the higher-temperature systems. More deeply buried samples have been partially reset within the Siwalik basin and provide constraints on the thermal and kinematic history of the fold-andthrust belt itself. The results suggest that peak source-area exhumation rates have been constant at $\sim 1.8 \mathrm{~km} \mathrm{Myr}^{-1}$ over the last $\sim 7 \mathrm{Ma}$ in central Nepal, whereas they ranged between 1 and $\sim 1.5 \mathrm{~km} \mathrm{Myr}^{-1}$ in western Nepal over the same time interval; these spatial variations may be explained by either a tectonic or climatic control on exhumation rates, or possibly a combination of the two. Increasing lag times within the uppermost part of the sections suggest an increasing component of apatites that have been recycled within the Siwalik belt and are corroborated by AFT ages of modern river sediment downstream as well as the record of the
\end{abstract}


distal Bengal Fan. The most deeply buried and most strongly annealed samples record onset of exhumation of the frontal Siwaliks along the Himalayan frontal thrust at $\sim 2 \mathrm{Ma}$ and continuous shortening at rates comparable to the present-day shortening rates from at least 0.3 Ma onward.

\section{INTRODUCTION}

The Himalaya is by far the most important source of sediment input to the world's oceans (Summerfield \& Hulton, 1994; Hay, 1998); its denudation history should, therefore, have major consequences for global climate change if atmospheric $\mathrm{CO}_{2}$ drawdown from weathering and organic carbon burial plays a role in modulating climate (Raymo \& Ruddiman, 1992; France-Lanord \& Derry, 1997). Denudation rates within the Himalayan system may have fluctuated considerably through time, controlled by tectonic and/or climatic factors, such as the onset of the Asian Monsoon and global glaciations. The erosional history of the Himalaya, as inferred from mass-balance studies, is controversial: whereas some studies have inferred a significant Quaternary increase in sediment fluxes (e.g., Métivier et al., 1999), others have suggested that fluxes have been decreasing since reaching a peak in middle-late Miocene times (e.g., Burbank et al., 1993, Clift \& Gaedicke, 2002). Vance et al., (2003) and Vannay et al. (2004), using detrital cosmogenic and in-situ thermochronologic data respectively, have argued that denudation rates in the western Himalaya have increased significantly during the last few Myr. Burbank (1992) has demonstrated rebound of the Ganges foreland basin since $\sim 4 \mathrm{Ma}$, which he also attributes to increased denudation of the mountain belt since that time. Constraining the erosional history of the Himalaya is therefore important in order to elucidate both the mass fluxes at the Earth's surface and the climatic and tectonic controls on mountain building. Some of the questions that are of interest to us include: What is the recent cooling history of the Himalayas? Has exhumation of the Himalayas in Nepal been continuous or episodic since the mid-Miocene? Is the exhumation history of the Himalayas controlled purely by tectonics or can we isolate climatic controls?

Detrital thermochronology permits monitoring the evolution of cooling and exhumation rates through time by analysing samples from sediments of different ages derived from an eroding mountain belt. Thus, detrital thermochronology provides a much longer "memory" of exhumation rates than in-situ thermochronology, especially in regions of high exhumation rates and therefore young thermochronological ages such as the Himalaya. A key concept of detrital thermochronology is the "lag time" (Garver et al., 1999; Bernet et al., 2001), defined 
as the difference between the thermochronological and the depositional ages of the sample and, therefore, the time the sample spent to reach the surface from its closure temperature and be deposited in the basin (Figure 1). Transport times are generally considered negligible; the lag time is thus a direct measure of exhumation rates within the source area at the time of deposition. Since synorogenic sediments may be derived from different sources in a mountain belt, characterized by varying denudation histories, detrital samples usually contain a range of cooling ages, which can be divided into different grain-age components or peaks (e.g., Bernet et al., 2001; 2004; Stewart \& Brandon, 2004).

Most detrital thermochronology studies have employed thermochronometers with relatively high closure temperatures $\left(T_{c}\right)$ such as zircon fission-track (ZFT; $T_{c} \approx 240^{\circ} \mathrm{C}$; e.g. Cerveny et al., 1988; Bernet et al., 2004) or mica ${ }^{40} \mathrm{Ar} /{ }^{39} \mathrm{Ar}\left(T_{C}=350-420^{\circ} \mathrm{C}\right.$; e.g. Copeland \& Harrison, 1990; White et al., 2002; Szulc et al., 2006). The effective closure temperature of any thermochronological system will determine what type of process can be addressed by its study: the time and length scales of constraint will depend on closure temperature, so that in any region, higher-temperature systems will constrain deeper, longer-term processes than lower-temperature systems (Figure 1). Therefore, using a lower-temperature thermochronometer, such as the apatite fission-track (AFT) system $\left(T_{c}=110 \pm 10^{\circ} \mathrm{C}\right)$, in conjunction with these higher-temperature systems makes it possible, in principle, to track short-term variations in denudation rates that are below the resolution of the highertemperature systems. In-situ bedrock AFT ages within the western and central Himalaya are consistently younger than a few Ma (e.g., Jain et al., 2000; Thiede et al., 2004; Blythe et al., 2006) so that, in principle, variations in exhumation rates can be monitored with a temporal resolution of 1-2 Myr.

The relatively low closure temperature of the AFT thermochronometer, however, makes this system also more sensitive to post-depositional heating within the sedimentary basin. As a sample is buried deeper in the sedimentary basin and reaches temperatures corresponding to the AFT partial annealing zone $\left(\mathrm{PAZ} ; 70-120^{\circ} \mathrm{C}\right)$, the information it contains concerning source-area exhumation is progressively erased (Figure 1). Samples that have been buried to depths less than the PAZ retain a source-area signal; their component ages are older than the depositional ages and increase down-section, indicating they are unreset and can be interpreted in terms of lag times (Figure 1b). For samples exhumed from within the PAZ, in contrast, annealing will partially reset the peak ages, which thus lose their geological significance. Partially reset ages may be either older or younger than the depositional age; as the intensity of annealing increases with depth (temperature), peak ages of partially reset 
samples will thus generally decrease down-section. Moreover, since the kinetics of AFT annealing vary with apatite chemistry (e.g., Carlson et al., 1999; Barbarand et al., 2003), with low-retentive grains becoming (partly or fully) reset at lower temperature than high-retentive grains, we may expect a stronger variability in single-grain ages in such samples compared to unreset samples from the same source. This loss of information is, however, counterbalanced by complementary constraints on the post-depositional thermal history, which will be most clearly recorded by the deepest and most strongly annealed samples (Rohrman et al., 1996; Carter \& Gallagher, 2004; Cederbom et al., 2004). In these samples, an increasing proportion of apatite grains will have been completely reset within the basin, such that the youngest component age peak will regain geological significance: it dates the onset of exhumation of the basin strata (Brandon et al., 1998; Locke \& Garver, 2005). This situation manifests itself when minimum ages (that is, the age of the youngest component peak) are similar for different samples (Figure 1b). Finally, if all of the apatites have been completely reset within the basin, a single peak age dating the onset of basin exhumation is expected. A more complete retrieval of the post-depositional thermal history is obtained when confined fission track-length distributions are considered together with the age distributions of the samples (Gallagher et al., 1998; Carter \& Gallagher, 2004).

In this paper, we present detrital AFT data from 31 samples collected from Miocene to Pliocene stratigraphic sections of the Siwalik Group at the Karnali River, Surai Khola, and Tinau Khola sections in western and central Nepal, as well as three samples from modern river sediments from the same area (Figure 2). These data complement detrital ZFT ages from the same sections presented in a companion paper (Bernet et al., 2006). Samples from the upper part of the stratigraphic sections provide complementary constraints on source-area denudation rates, and show spatial variations in denudation rates that are not picked up by the higher-temperature systems, whereas more deeply buried samples provide constraints on the thermal and kinematic history of the Siwalik fold-and-thrust belt itself.

\section{TECTONIC AND GEOMORPHIC SETTING}

The Himalaya is classically subdivided into four tectonic zones (e.g., Hodges 2000, Yin \& Harrison 2000) that can be followed along its $\sim 2500 \mathrm{~km}$ length and are separated by northdipping crustal-scale faults, branching off the main detachment overlying the underthrust Indian plate (Zhao et al., 1993; Yin \& Harrison, 2000; Avouac, 2003). The northernmost Tethyan Himalayan zone forms the southern border of the Tibetan Plateau and consists of 
Cambrian to Eocene sedimentary to low-grade metamorphic rocks. It is separated from the structurally underlying Higher (or Greater) Himalayas by the extensional Southern Tibetan Detachment System (STDS; Burchfiel et al., 1992). The Higher Himalayan zone consists of high-grade metamorphic rocks and forms the topographic backbone of the range. It is intruded along its northern border by Miocene ( 24-17 Ma) leucogranites (Burchfiel et al., 1992, Guillot et al., 1994, Hodges et al., 1996). The Higher Himalaya overthrusts the Lesser Himalaya along the Main Central Thrust (MCT; Figure 2). Precise dating of the activity of the STDS and MCT has shown that they were active simultaneously during the Early Miocene (around 22-18 Ma; Burchfiel et al., 1992, Hodges et al., 1996), giving rise to a model of extrusion of Greater Himalayan middle crust from under the overthickened Tibetan Plateau (Beaumont et al., 2001, Hodges et al., 2001).

The Lesser Himalaya consists mainly of Proterozoic to Palaeozoic (meta)sedimentary rocks and is bounded to the south by the Main Boundary Thrust (MBT). In western Nepal, the Lesser Himalaya forms a complex structural duplex with several major internal thrusts (DeCelles et al., 2001). Overall, the timing of activation of thrusts in the Lesser Himalaya indicates a forward-propagating thrust sequence with activity of the MCT initiating $>20 \mathrm{Ma}$, the internal thrusts between 10-20 Ma (DeCelles et al., 2001; Huyghe et al., 2005), and the MBT between 5 Ma (DeCelles et al., 2001) and 10 Ma (Meigs et al., 1995; Huyghe et al., 2001). The MBT overthrusts the Sub-Himalaya or Siwalik thrust belt, composed of MioPliocene syn-tectonic clastic deposits. The latter overthrusts the Ganges plain (known as Terai plain in Nepal) along the currently active Main Frontal Thrust (MFT).

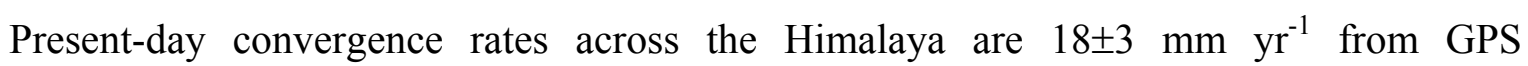
measurements (Bilham et al., 1997; Larson et al., 1999; Jouanne et al., 2004). Within error, these are equal to Holocene shortening rates across the MFT (Lavé \& Avouac, 2000; Mugnier et al., 2004) inferred from folded and uplifted river terraces. They are also equal to Quaternary shortening rates across the Siwalik fold belt (Mugnier et al., 2004) and MioPliocene shortening rates across the Lesser Himalaya (DeCelles et al., 2001) inferred from section balancing. Moreover, a frontal propagation rate that is equal to the convergence rate can be inferred from facies-migration patterns within the Ganges foreland basin, suggesting overall steady-state forward migration of the Himalayan orogenic wedge since $\sim 15 \mathrm{Ma}$ (Lyon-Caen \& Molnar, 1985; Avouac, 2003; Mugnier \& Huyghe, 2006). Combining presentday patterns and rates of uplift and deformation from geodetic studies with those obtained on geological timescales, Avouac (2003) has proposed a model in which convergence takes place over a mid-crustal detachment including a ramp underlying the topographic front of the 
Higher Himalaya (see also Bilham et al., 1997; Cattin \& Avouac, 2000; Lavé \& Avouac, 2001; Bollinger et al., 2004). From a detailed analysis of GPS data, Larson et al. (1999) and Berger et al. (2004) have proposed that the detachment is segmented and the crustal ramp more pronounced in central Nepal than in western Nepal. Recently, however, a competing model has been proposed that incorporates out-of-sequence activation of a newly formed thrust just south of the MCT, possibly controlled by climatic focussing of erosion on the topographic front of the Higher Himalaya (Wobus et al., 2003; Hodges et al., 2004).

A growing number of in-situ fission-track thermochronology studies have emphasized the rapid rates of recent exhumation within the central Himalaya (e.g., Arita \& Ganzawa, 1997; Jain et al., 2000; Burbank et al., 2003; Thiede et al., 2004; Vannay et al., 2004; Bojar et al., 2005; Blythe et al., 2006). Most of these studies have concentrated on the Higher Himalaya and the Lesser Himalayan crystalline zones, due to the unfavourable lithologies in the other tectonic units of the central Himalaya. Within these zones, AFT ages of valley samples are commonly $\leq 1 \mathrm{Ma}$, rising to 2-4 Ma for the highest-elevation samples. In detail, however, there are some differences between the different results: extremely young AFT ages $<0.5 \mathrm{Ma}$ (e.g., Burbank et al., 2003; Bojar et al., 2005) are not reproduced in all studies, and whereas Burbank et al. (2003) report a jump in ages across the MCT in the Marsyandi area of central Nepal, Thiede et al. (2004), Vannay et al. (2004) and Bojar et al. (2005) show that AFT ages remain young in the Lesser Himalayan crystalline zone in the Goriganga and Sutlej regions ( $\sim 400$ and $700 \mathrm{~km}$ west of the Marsyandi, respectively). Higher closure-temperature ${ }^{40} \mathrm{Ar} /{ }^{39} \mathrm{Ar}$ mica ages show a similar pattern (Bollinger et al., 2004, Vannay et al., 2004): they are commonly 4-6 Ma in the northernmost Lesser Himalaya in the footwall of the MCT and increase to $\sim 20 \mathrm{Ma}$ in the southernmost part of the Lesser Himalaya along the MBT hangingwall.

\section{Stratigraphy and structure of the Siwalik belt in western Nepal}

The Siwalik fold-and-thrust belt constitutes the active deformation front of the Himalaya and the deformed part of its Neogene foreland basin. The belt can be subdivided into a structurally simple outer belt, composed of laterally propagating fault-bend or fault-propagation folds associated with the MFT and their hanging wall synclines, on which wedge-top basins or Duns have developed; and a more complex inner belt composed of a series of laterally relayed and transported thrust sheets (Figure 3; Mugnier et al., 1993, 1999; Champel et al., 2002; Husson et al., 2004). On the basis of growth strata recognised within the Surai Khola section 
in central Nepal, Mugnier et al. (2004) infer an onset of thrusting on the MFT between 1.8 and 2.4 Ma.

Siwalik Group sediments were deposited in the Ganges foreland basin during Middle Miocene-Pliocene times (e.g., Burbank et al., 1996) and constitute an upward-coarsening fluvial megasequence (DeCelles et al., 1998; Nakayama \& Ulak, 1999; Huyghe et al., 2005). The Siwalik Group is traditionally subdivided into the Lower-, Middle-, and Upper Siwalik subgroups (cf. Figure 3). The Lower Siwaliks consist of mudstones and fine- to mediumgrained sandstones with common palaeosol horizons and are interpreted as representing deposition in a fine-grained meandering fluvial system. The Middle Siwaliks are mainly massive coarse-grained micaceous sandstones and record a transition from sandy meandering to sandy braided fluvial environments. The Upper Siwaliks are composed of pebble- to boulder-sized conglomerates representing deposition in gravely braided streams and alluvial fans. Overall, the evolution of depositional environments records the forward propagation of the Himalayan thrust wedge and increasing proximity of the source area, although regional climate changes also influenced the depositional settings (Quade et al., 1995; Nakayama \& Ulak, 1999; Huyghe et al., 2005).

The present-day drainage pattern of the Nepal Himalaya is characterized by a small number of through-going trunk rivers (the Karnali in western Nepal, Narayani in central Nepal and Sapt Kosi in eastern Nepal) that collect the drainage of many tributaries before cutting through the Siwalik ranges. The characteristic gridiron drainage pattern thus formed has been interpreted to result from thrust-related uplift along the MBT during Late Miocene times (Gupta, 1997). Lateral drainage diversion is also common within the Siwalik belt and is a response to uplift and lateral propagation of the active fault-related folds along the MFT (Champel et al., 2002; van der Beek et al., 2002). In contrast, flow directions measured within the Siwalik sediments are consistently toward the south, indicating transverse transport similar to the modern drainage pattern in the northern Ganges flood-plain (Tokuoka et al., 1990; DeCelles et al., 1998; Szulc et al., 2006).

As the Siwaliks have been tilted and exhumed along the MFT, several continuous crosssections through the sequence are exposed where rivers cut across the frontal structure (Figures 2 and 3), providing a well-constrained framework for sampling the tectonic and climatic record contained within the Siwalik Group sediments in magneto-stratigraphically dated sections (e.g., Harrison et al., 1993; Quade et al., 1995; DeCelles et al., 1998; Huyghe et al., 2001, 2005; Robinson et al., 2001). 
The first magneto-stratigraphic dating studies in western Nepal were carried out along the Surai Khola (Appel et al., 1991) and Tinau Khola (Gautam \& Appel, 1994) sections; these results have been reinterpreted and calibrated to the Cande \& Kent (1995) magnetic polarity timescale by Gautam \& Rösler (1999). The Surai Khola preserves the most completely dated stratigraphic section; the Tinau Khola section is cut off within the Middle Siwaliks by an internal thrust. Gautam \& Rösler (1999) put the Lower-Middle Siwalik boundary at $\sim 9.8 \mathrm{Ma}$ (base of chron 4a) in these sections and the Middle-Upper Siwalik boundary at 5.2 Ma (base of chron 3). This calibration has been questioned, however, on the basis of vertebrate fossil data, which would suggest the Middle-Upper Siwalik limit should be younger than $3.5 \mathrm{Ma}$ (Corvinus \& Rimal, 2001). More recently, these sections have been resampled by a University of Arizona team (T.P. Ojha, pers. commun., 2003). Although the magneto-stratigraphic results themselves have not been published, they have been used to provide a temporal framework for several paleo-climate and provenance studies (e.g., Hoorn et al., 2000; Robinson et al., 2001; Szulc et al., 2006). Whereas the difference between the two magnetostratigraphic frameworks for any horizon is never more than 1 Myr for the Tinau section, it reaches $>2$ Myr in the Middle Siwalik subgroup in the Surai section (cf. Fig. 4 in Szulc et al., 2006). Ojha's unpublished data put the Lower-Middle Siwalik transition at $8.2 \mathrm{Ma}$ in the Surai section and 10.3 Ma in the Tinau section, whereas they date the Middle-Upper Siwalik transition at 3.5 $\mathrm{Ma}$ in the Surai section. Finally, a long magnetostratigraphic record is available for the Karnali River section, encompassing Lower and Middle Siwalik subgroups between 15.9 and 5.2 Ma (Gautam \& Fujiwara, 2000).

\section{DETRITAL APATITE FISSION-TRACK THERMOCHRONOLOGY}

\section{Sampling and Methods}

We collected samples for detrital apatite and zircon fission-track analysis along the Surai, Tinau, and Karnali River sections, aiming to collect a sample every million years represented by the sedimentary succession. For the Karnali section we had access to detailed field logs, enabling us to locate and identify $\sim 90 \%$ of the holes drilled for the Gautam \& Fujiwara (2000) magnetostratigraphic study; we are thus able to tie our data very closely to the magnetostratigraphy. Samples KAR14 and KA30 were collected from Middle and Upper Siwalik series stratigraphically above the dated section; their ages were estimated by extrapolating the deposition rates recorded by the magnetostratigraphy. For the Surai and Tinau sections, we tied our data to the Appel et al. (1991) and Gautam \& Appel (1994) 
studies using the most detailed maps and logs available (e.g., Tokuoka et al., 1990; Corvinus \& Rimal, 2001) and to the unpublished Ojha data by tying them to the sampling sites of Szulc et al. (2006). We estimate uncertainties on the stratigraphic ages to be of the order of the length of the recognised polarity chrons, i.e. \pm 0.1-0.2 Myr, except for the youngest samples which have larger errors because they are based on extrapolated deposition rates (in the Karnali section) or because the magnetostratigraphy has low resolution (in the uppermost part of the Surai section).

In the following, we will use the stratigraphic depth of samples as a common reference for the different sections (cf. Figures 4 and 7). As none of the sections record continuous sedimentation to the present-day, the maximum depth reached by the samples is not well constrained. The youngest Upper Siwalik sediments in the Surai Khola section have an estimated age of $1.0 \pm 0.5 \mathrm{Ma}$ and are overlain by a few hundred meters of younger conglomerates. In the Karnali section, a minimum estimated thickness of $1500 \mathrm{~m}$ of upperMiddle and Upper Siwalik series overlies the magneto-stratigraphically dated section. However, in both cases the Upper Siwaliks are clearly syntectonic (Mugnier et al., 2004; Huyghe et al., 2005) and their thickness may vary strongly laterally, with thick deposits limited to the footwalls of major internal thrusts (Figure 3). Because the Tinau section is cut off by an internal thrust, no estimate of the overlying sediment thickness can be made in the field. We estimated maximum stratigraphic depth in all three sections by extrapolating the sedimentation rates calculated from the magnetostratigraphic data to the present day (cf. Figure 4). This approach tends to overestimate the maximum depth reached by the samples by minimising the age of cessation of deposition at the section locations. However, the extrapolated sediment thickness is close to the thickness of overlying sediments observed in the field. Moreover, the stratigraphic age-depth curves we obtain are consistent between the three sections studied, lending a degree of confidence to our approach. Note that the use of stratigraphic depth is not central to our analysis; it mainly serves to compare the structural positions of samples from different sections and to estimate geothermal gradients from the data.

Apatites were recovered from whole-rock samples using standard magnetic and heavy liquid separation techniques, mounted in epoxy, polished and etched in a $5 \mathrm{M} \mathrm{HNO}_{3}$ solution at $20^{\circ} \mathrm{C}$ for $20 \mathrm{~s}$. All samples were dated by the external detector method, using U-poor mica as an external detector and a zeta calibration factor for Fish Canyon and Durango age standards (Hurford 1990). Samples were irradiated at the well-thermalized ORPHEE facility of the Centre d'Etudes Nucléaires in Gif-sur-Yvette, France, with a nominal fluence of 
$\sim 5 \times 10^{15}$ neutrons $/ \mathrm{cm}^{2}$. Neutron fluences were monitored using NBS962 dosimeter glasses. Mica detectors were etched in $48 \% \mathrm{HF}$ at $20^{\circ} \mathrm{C}$ for 20 minutes. All datable grains (including zero-track grains) within a mount were included in the analysis; grains were selected for dating primarily on the basis of the grain images in the mica detectors. For the Karnali River section, where apatite yield was highest, confined track-length measurements were performed on separate mounts, after irradiation with ${ }^{252} \mathrm{Cf}$-fission fragments (at University College London) in order to increase the probability of revealing confined tracks. Track lengths were measured by digitizing the track ends using a drawing tube. For these apatite samples, the etch-pit width parallel to the $\mathrm{C}$-axis $\left(\mathrm{D}_{\mathrm{par}}\right)$ of 100 tracks crossing the etched internal surface was measured using the same digitizing technique, in order to constrain their annealing kinetics (e.g., Carlson et al., 1999; Barbarand et al., 2003).

\section{Results}

Apatite fission-track ages are reported as central ages (Galbraith \& Laslett 1993) with $\pm 2 \sigma$ uncertainties in Table 1. Although the use of central ages is common in reporting AFT results, these only have geological significance for samples that contain a single age population (as indicated by a chi-square probability $P\left(\chi^{2}\right)>5 \%$ and an age dispersion $D<15 \%$ ) and that are unreset. We determined the age populations making up our samples by binomial peak fitting (Brandon 1996, Stewart \& Brandon 2004); Table 2 reports the fitted component ages for the samples containing multiple age populations. Samples collected within the same polarity chron at a single section (e.g., samples KA441 + KAR1 in the Karnali section, samples BUT3 + TIN5 and BUT1 + TIN1 in the Tinau section), were first modelled individually and subsequently modelled together, in order to maximise the number of single-grain ages in the inversions. Thirteen of our samples can be fit by a single age population; the single binomial peak-fit age is equal to the central age. These samples are characterised by age dispersions $D$ $\leq 12 \%$. In the following, we will thus quote the central ages for samples containing a single population of grain ages, and the component peak ages (termed P1, P2, etc) for samples containing multiple populations. Representative radial plots and probability density plots of single-grain ages, together with the fitted age peaks, are shown in Figure 5.

Three samples from modern river sands were analysed, from the Trisuli and Marsyandi rivers just upstream of their confluence within the Lesser Himalaya about $100 \mathrm{~km}$ ENE of the Tinau River section, and from the Karnali River as it enters the Ganges plain just south of the Karnali River section (Table 1b). All three samples contain a single AFT age population. The Trisuli and Marsyandi samples show a similar age structure with a central AFT age of 
$\sim 1.8 \pm 0.4 \mathrm{Ma}$. The Karnali sample, in contrast, yields a surprisingly old AFT central age of $8.0 \pm 1.4 \mathrm{Ma}$.

Within the Surai section, none of three samples from the Lower Siwalik subgroup yielded sufficient apatite for meaningful age determinations; the deepest sample represented in this study is from a stratigraphic depth of $\sim 2700 \mathrm{~m}$ (1720 m above the base of the section). Unexpectedly, all of the Surai samples contain a single age population, consistent with the fact that they all pass the $\chi^{2}$ test and are characterised by small age dispersions $(\mathrm{D}<10 \%$ and mostly $\leq 1 \%$ ). Except for samples SUR1 and SUR20, which are significantly older than the underlying samples, AFT central ages increase down-section (Figure 4), suggesting that they are unreset. We thus interpret the central age to reliably date source-area exhumation for these samples. However, four out of the eight Surai samples have AFT central ages significantly younger than their depositional age, when using the Appel et al. (1991) magnetostratigraphic data (as recalibrated by Gautam \& Rösler, 1999), and one sample (SUR15) has an AFT age equal to its depositional age (Figure 6). The data appear more consistent with the unpublished magnetostratigraphy by T.P. Ojha, as all samples have AFT central ages older than their depositional age. For this reason, we will use this temporal framework, rather than the published data, in the remainder of this study for the Surai and Tinau sections. Szulc et al. (2006) provide a more detailed discussion of these different magneto-stratigraphic studies. Lag times for most Surai section samples are $\leq 1 \mathrm{Myr}$, except for the two 'anomalously' old samples SUR1 and SUR20, which have lag times of 4.3 and 5.3 Myr, respectively. Of these two, SUR1 has very low U-content (as indicated by the low track counts) and its age may be spurious. In contrast, we think the age of SUR20 is reliable and will come back to it in the discussion section.

Samples from the Tinau section mostly come from greater stratigraphic depths than those from the Surai section, between $\sim 2000$ and $\sim 4000 \mathrm{~m}$. Out of nine samples analysed, three contain a single age population (Tables 1 and 2), but two of these (TIN5 and TIN1) were collected from the same polarity chron as samples that show multiple age populations (BUT3 and BUT1, respectively) and were ultimately combined with these for calculating age groups (Table 2). Only the two uppermost Tinau samples have AFT central ages (TIN13) or P1 ages (TIN8) older than the stratigraphic age; for the others, both P1 and P2 peak ages are younger than the depositional age (except for TA18A which contains a minor P2 peak just older than the depositional age). These samples from below $\sim 2800 \mathrm{~m}$ stratigraphic depth are thus partially reset; a downward increasing intensity of annealing is indicated by the fact that 
central ages generally decrease down-section (Figure 4). P1 ages do not become constant down-section, however, suggesting that none of them (except possibly the youngest ones) represent a fully annealed grain population. Thus, neither the P2 nor the P1 peak ages are geologically significant, the latter only provide a maximum estimate for the onset of basin exhumation in this area.

Sample recovery was most complete from the Karnali River section, represented here by 14 samples from between $\sim 900 \mathrm{~m}$ and $\sim 5300 \mathrm{~m}$ stratigraphic depth. All but two of the Karnali section samples (KAR11, KA36) are characterised by multiple age populations (Tables 1 and 2). Samples from $\leq 2500 \mathrm{~m}$ stratigraphic depth have AFT central ages that increase with depth and that are significantly older than the depositional age (Figure 4). For samples containing multiple age populations, minimum (P1) ages are also older than the depositional age (except for sample KA34 from $2070 \mathrm{~m}$ depth, which contains a small and anomalously young P1 peak). We interpret these samples as generally unreset and representing a source-area denudation signal. The differences between the P1 age and the depositional age define lag times increasing downward from $\sim 2$ to $\sim 4$ Myr for the samples above $2500 \mathrm{~m}$ depth (Figure 7). The fact that lag times increase down-section for these samples is a strong indication that they are unreset, as partial annealing increases in intensity down-section and would reduce the peak ages and thus the lag times. Three samples (KA36, KAR10, KAR9) between 2500 and 2900 m depth have variable AFT ages, with P1 peaks both older and younger than the depositional age. Samples from below $3000 \mathrm{~m}$ stratigraphic depth (i.e., within the lowermost $2000 \mathrm{~m}$ of the section) have central ages generally decreasing down-section, and both P1 and P2 peaks that are younger than the depositional age, indicating partially reset samples. P1 ages generally decrease down-section but are constant, with a mean of $2.1 \pm 0.3 \mathrm{Ma}$, for the lowermost four samples (Figure 7, see also Figure 5), suggesting that these represent a fully reset group of apatites and indicate the onset of final exhumation of the basin strata. This age overlaps the two youngest P1 peaks from the Tinau section samples (BUT4 and BUT1+TIN1).

Four samples from the Karnali section and two from the Tinau section show minor P3 populations with ages between 14 and $35 \mathrm{Ma}$, i.e. much older than the depositional ages, even for the deepest samples. If these are not artefacts, they must represent exceptionally resistant apatites derived from areas of relatively low denudation rates. However, because these age groups are defined by very small numbers of grains, the error on the peak ages are typically larger than the peak age itself, rendering any interpretation of these very hazardous. 
Track-length measurements were performed on eight samples from the Karnali River section and one from the Tinau section (Table 3). Track-length histograms for the Karanali samples are plotted in Figure 7. Due to the low track densities in these samples and the relative paucity of material, between 36 and 80 lengths only could be measured, even after ${ }^{252} \mathrm{Cf}$ irradiation. Mean track lengths vary between 11.0 and $12.0 \mu \mathrm{m}$ for non-reset samples (with corresponding standard deviations of 2.0-3.0 $\mu \mathrm{m}$ ), suggesting complex source-area exhumation paths. They decrease down-section to $\sim 9.5 \mu \mathrm{m}$ in the deepest, most strongly annealed samples. Samples from intermediate depths, between 2000 and $~ 3000 \mathrm{~m}$, show bimodal distributions (e.g., KAR12, KAR11, KAR9), whereas track-length distributions from deeper samples become positively skewed, indicative of increasing annealing intensities down-section (Gallagher et al., 1998). Etch-pit widths ( $\left.\mathrm{D}_{\mathrm{par}}\right)$ show little variation, both within single samples and between samples. $\mathrm{D}_{\text {par }}$ values vary between 1.2 and $1.8 \mu \mathrm{m}$, with standard deviations of 0.3-0.4 $\mu \mathrm{m}$. Six out of nine samples have a $\mathrm{D}_{\text {par }}$ between 1.6 and $1.8 \mu \mathrm{m}$ (Table 3), indicating annealing behaviour close to that of Durango apatite (e.g., Carlson et al., 1999; Barbarand et al., 2003).

\section{DISCUSSION}

Interpreting the above results is not an easy task because our samples combine variable source signals with varying degrees of thermal resetting. This leads to a wide variety of single-grain age structures between the samples: some samples are characterised by a single grain-age population whereas others have multiple component ages; both minimum and central ages can be either older or younger than the depositional age. Typical uncertainties on the AFT central or component ages are $>15 \%$ and will propagate into inferred source area or basin exhumation rates. Compared to these error bars, the uncertainties on the depositional ages are relatively small, but we have to accept the magnetostratigraphy at face value (except for the Surai section, see above). Although formal 95\% confidence limits on our reconstructed burial depths are very small (typically 10-15 m), we have no way of independently testing our stratigraphic depth model. This does not strongly influence our inferences, however, other than for determining the geothermal gradient (see below). Finally, some of the results are spurious, falling outside of the trends defined by under- and overlying samples (e.g., SUR1, KAR10). Nevertheless, when combining all the data, some clear trends do arise and we will construct our interpretation of the data on the basis of these general trends. 
Combining the data from all three sections (e.g., Figure 4) shows a consistent transition from unreset to partially reset samples between 2500 and $2800 \mathrm{~m}$ reconstructed stratigraphic depth. Studies of AFT annealing from thermally calibrated wells (see Gallagher et al., 1998 for a review), as well as annealing models based on experimental data (e.g., Ketcham et al., 1999), indicate that significant AFT annealing under geological timescales begins at temperatures of $70-80^{\circ} \mathrm{C}$ (cf. Figure 1), thus providing us with a temperature benchmark in the sections. These inferred temperatures are consistent with vitrinite reflectance data from a limited number of samples from the upper part of the Karnali section (L. Martinez, Pers. Commun. 2003), which suggest maximum temperatures between 62 and $75^{\circ} \mathrm{C}$ at depths between 1700 and $2600 \mathrm{~m}$. Likewise, Mugnier et al. (1995) reported vitrinite reflectance $\left(R_{0}\right)$ values of $0.3-0.5 \%$ for Middle Siwalik and $0.6-1.0 \%$ for Lower Siwalik sediments in westcentral Nepal, corresponding to maximum burial temperatures of $60-90^{\circ} \mathrm{C}$ and $>100^{\circ} \mathrm{C}$, respectively. Huyghe et al. (2005) estimated temperatures of $70-95^{\circ} \mathrm{C}$ at depths $>2100 \mathrm{~m}$ in the Karnali section from illite crystallinity. These different depth-temperature couples indicate a geothermal gradient of $18-24{ }^{\circ} \mathrm{C} \mathrm{km}^{-1}$ (assuming a mean surface temperature of $20^{\circ} \mathrm{C}$ ), consistent with temperature measurements in wells located in the Siwaliks of western India (Agarwal et al., 1994). This overall consistency suggests that our paleo-depth estimates from the extrapolation of sedimentation rates are reasonable.

Because of the fundamentally different information that is to be gained from unreset samples, retaining a source-area signal, and partially to fully reset samples, recording the post-depositional thermal evolution, we discuss these two sets of samples separately below.

\section{Source-area denudation rates}

Figure 8 shows a lag-time plot for all non-reset samples from the three sections analysed. The AFT ages plotted in this figure are either the central age (for samples with a single age population) or the youngest (P1) peak age (for samples with multiple age components).

Samples from the Surai section are aligned along a constant lag time trend of $\leq 1 \mathrm{Myr}$, with the exception of the outliers SUR20 and SUR1, whereas samples from the Karnali section appear to indicate lag times that decrease up-section, from $\sim 4 \mathrm{Myr}$ at $\sim 7 \mathrm{Ma}$ (KAR11, KA36) to $\sim 2 \mathrm{Myr}$ at the top of the section. Alternatively, the Karnali data can be interpreted as two more or less constant lag-time trends at $\sim 4 \mathrm{Myr}$ and $\sim 2 \mathrm{Myr}$, respectively, and a sharp jump from one to the other at $\sim 6.5 \mathrm{Ma}$. Note, however, that the three samples which define the $\sim 4$ Myr lag time contain a single age population and we thus use their central ages, whereas for the younger samples with shorter lag times we use the P1 ages. On the other 
hand, bimodal track-length distributions in these lower samples (Figure 7) indicate an onset of partial annealing which would tend to decrease the ages and lag times.

Bernet et al. (2001) suggested a simple test for constancy of lag times by performing a linear correlation of FT peak ages $\left(t_{c}\right)$ to depositional ages $\left(t_{d}\right)$ : if lag times are constant, the slope to the correlation line should be $\sim 1$; if it is $>1$, lag times decrease up-section and if it is $<1$, they increase up-section. For the Surai samples (excluding the outliers SUR20 and SUR1), the slope of the correlation line (weighted by the uncertainties on both the magnetostratigraphic and AFT ages; Williamson, 1968) is $1.18 \pm 0.18$ (95\% confidence limit; $\mathrm{r}^{2}=0.93$ ), consistent with a constant lag time of $0.8 \pm 0.5$ Myr (weighted mean $\pm 95 \%$ confidence limit). This mean lag time is consistent with published in-situ AFT ages from samples closest to this section, in the upper Marsyandi valley in central Nepal (Blythe et al., 2006), but significantly smaller than the central ages of the two present-day sediment samples we collected in rivers draining the central Nepal Himalaya (samples MAR6 and MAR10). Note that, at present, sediments from the Marsyandi and Trisuli catchments leave the Himalayan system along the Narayani River, approximately $120 \mathrm{~km}$ east of the Surai. Sedimentology and source area indicators for the Middle and most of the Upper Siwaliks of the Surai section, however, clearly indicate that these were fed by a drainage system originating in the Higher Himalaya (Huyghe et al., 2001; 2005; Robinson et al., 2001; Bernet et al., 2006; Szulc et al., 2006).

For the Karnali section, in contrast, the slope of the correlation line is $1.40 \pm 0.22(95 \%$ confidence limit; $r^{2}=0.93$ ), indicating lag times that decrease up-section, with a weighted mean of $2.5 \pm 0.9$ Myr. No in-situ thermochronological data exist in Western Nepal to compare these with. The difference in lag times between the two sections, however, is significant.

These spatial variations in lag times do not show up as clearly in the detrital zircon data presented in the companion paper (Bernet et al., 2006), principally because the zircon yield from the Karnali section is low. In order to compare the apatite and zircon data more quantitatively, we transformed lag times for both datasets to source-area exhumation rates using a modified version of the simple one-dimensional model of Brandon et al., (1998). This model takes into account the advective perturbation of an initially linear geotherm by rock exhumation, as well as the dependence of closure temperature on cooling rate (e.g., Dodson 1973). It does not, however, include 2D or 3D effects such as non-vertical rock-particle paths, spatial variation in exhumation rates or topographic effects. Where both zircon and apatite 
data are available for the same sample, we combine ZFT and AFT ages to predict an initial exhumation rate between the ZFT and AFT closure temperatures and a final rate between the AFT closure temperature and the surface. This procedure permits us to predict exhumation rates that are consistent with both sets of data. We predict exhumation rates using the central age for samples with a single age population, or the P1 age for samples containing multiple age components. The implication is that the model exhumation rate corresponds to the most rapidly exhuming part of the source area, which we will term 'peak exhumation rates' in the following.

Model results are shown in Figure 9, for the Surai and Karnali sections. Error bars on the predicted exhumation rates are calculated from the $2 \sigma$ error on the (peak or central) ages; where these overlap with the depositional age the maximum exhumation rate becomes infinite. Within the Karnali section, apatite and zircon data consistently predict peak exhumation rates of $1.3 \pm 0.3 \mathrm{~km} \mathrm{Myr}^{-1}$. Within the Surai section, ZFT data indicate relatively constant peak exhumation rates of $1.5 \pm 0.4 \mathrm{~km} \mathrm{Myr}^{-1}$, whereas AFT data are more variable and predict higher peak exhumation rates of $3.5 \pm 2.1 \mathrm{~km} \mathrm{Myr}^{-1}$ between 7 and $4 \mathrm{Ma}$. The above values are simple arithmetic means of the predicted exhumation rates for each sample. When taking the uncertainties in exhumation rates (due to the error on the ages) into account and calculating weighted means, the difference between rates predicted using the two systems disappears. This is because the high predicted exhumation rates for AFT data in the Surai section result from very short lag times with large relative errors, mostly overlapping with the depositional age. The weighted mean predicted exhumation rates from both AFT and ZFT data for the Surai section (again excluding SUR1 and SUR20) is $1.8 \mathrm{~km} \mathrm{Myr}^{-1}$. AFT and ZFT data from present-day river sands upstream of the Siwaliks (the Marsyandi and Rapti rivers, respectively) also consistently indicate peak source-area exhumation rates of 1.5 to $1.6 \mathrm{~km}$ $\mathrm{Myr}^{-1}$.

The inferred difference in peak source-area exhumation rate between the Karnali and Surai sections thus appear real, amounts to $\sim 500 \mathrm{~m} \mathrm{Myr}^{-1}$ over the last $\sim 7 \mathrm{Myr}$ and requires an explanation. Lower long-term exhumation rates in the Karnali catchment, with respect to central Nepal, are consistent with the preservation of klippen of Higher Himalayan and Tethyan rocks in western Nepal, whereas these have been removed by erosion in central Nepal (cf. Figure 2). Both tectonic and climatic effects may control such lateral variations in exhumation rate along the Himalayan front. Thiede et al. (2004) and Bookhagen et al. (2005) suggested that Himalayan exhumation rates are highest where monsoonal precipitation 
penetrates into the orogen along major river valleys and is focussed on the orographic barrier formed by the High Himalaya. The Narayani catchment in central Nepal may be one of these erosional "hotspots", as shown by the precipitation maps published by Thiede et al. (2004) and Bookhagen et al. (2005), and the predicted stream power map of Finlayson et al., 2002), whereas precipitation appears not to penetrate deeply into the orogen in the Karnali catchment. From a tectonic point of view, Berger et al. (2004) modelled present-day deformation in Nepal to show that the mid-crustal ramp underlying the Himalayan topographic front is much larger in central Nepal than in western Nepal. As spatial variations in exhumation rates may be controlled to a large extent by material being pushed up this ramp (e.g., Lavé \& Avouac, 2001; Avouac, 2003; Bollinger et al., 2004), the Berger et al. (2004) results imply higher exhumation rates in central Nepal compared to western Nepal. It is possible that the tectonic and climatic controls are linked through the cross-sectional topography of the mountain belt, which is much more concave in central Nepal than in western Nepal (Berger et al., 2004).

The data do not provide evidence for a significant increase in source-area denudation rates over the last few Myr, as has been inferred from the foreland basin stratigraphy (Burbank, 1992) and from comparisons of high- and low-temperature thermochronometers (Vance et al., 2003; Vannay et al., 2004). In contrast, the youngest samples appear to have intriguingly old AFT ages. SUR20 (depositional age 1.0 $\pm 0.5 \mathrm{Ma}$ ) has an AFT lag time of 5.2 Myr, longer than any of the other samples in this study and which cannot be attributed to artefacts due to low-U contents such as in sample SUR1. The modern Surai is a minor stream draining only the Siwalik Hills, but the regional drainage pattern suggests it was previously connected to the headwaters of the Rapti River before the latter was diverted by movement along the MFT (e.g., Champel et al., 2002). We thus expect that the modern Surai exclusively carries sediments that have been recycled within the Siwaliks, which would explain this anomalously old AFT age. The appearance of an important recycled component within the Upper Siwaliks may therefore indicate the onset of movement along the MFT between 4.0 \pm 0.2 and $1.0 \pm 0.5 \mathrm{Ma}$ (i.e. the depositional ages of samples SUR17 and SUR20, respectively). The importance of sediment recycling in the Siwaliks is also suggested by the modern sediment sample collected from the Karnali River where it leaves the Siwaliks and enters the Ganges plain. Although this sample yielded only 25 datable apatites, they have a

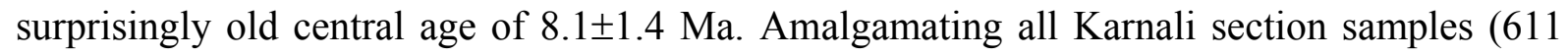
single-grain ages) results in an indistinguishable central age of 7.6 $\pm 0.4 \mathrm{Ma}$. This virtual 
"mixed Siwaliks" sample contains three age components of $3.0 \pm 0.4,8.1 \pm 2.0$ and 11.2 $\pm 3.0 \mathrm{Ma}$ respectively, the $8.1 \mathrm{Ma}$ age peak representing $\sim 50 \%$ of the single-grain ages. It thus appears likely that the modern Karnali River sample downstream of the Siwaliks contains almost exclusively recycled apatites. A modern sediment sample taken upstream of the section and for which Bernet et al. (2006) report detrital ZFT ages, would have been able to test this inference but unfortunately did not yield sufficient apatite for analysis.

Further evidence for significant recycling of apatites within the Siwalik sediments, however, comes from a comparison of our results from three proximal sections, with those of Corrigan \& Crowley (1990) from two ODP sites in the distal Bengal Fan. We calculated component ages from the Corrigan \& Crowley (1990) dataset using the same approach as for our own data (Table 4) and plot the obtained minimum (P1) ages as a function of depositional age in Figure 10. Except for the lowermost three samples from Site 718, which Corrigan \& Crowley (1990) argue are partially reset, the data show lag times of $1.7-8.3$ Myr with a weighted mean $4.4 \pm 1.9 \mathrm{Myr}$, i.e. significantly longer than the lag times measured in our study.

Thus, it appears that sediment recycling within the Siwaliks has a major impact on detrital AFT age distributions of samples collected downstream. In contrast, no significant recycling of Siwalik sediments is evident from detrital zircon or mica ages, whether these were collected from the Upper Siwalik subgroup (Bernet et al., 2006; Szulc et al., 2006), from Bengal Fan sediments (Copeland \& Harrison, 1990) or from modern river sediment in the foreland (Clift et al., 2004; Campbell et al., 2005). We have no satisfactory explanation for this apparent contradiction at present. Further constraining the role of sediment recycling within Siwalik sediments will thus require more detailed multi-method analyses on presentday and recent sediments.

\section{Thermal and kinematic history of the foreland basin}

Whereas the non-reset samples provide insight into the history of source-area exhumation, the deeper, partially annealed samples record the post-depositional burial and exhumation history within the Siwalik basin. As all three sampled sections occur in the hanging wall of the MFT (e.g., Figures 2 and 3), the exhumation history is directly linked to the kinematics of the currently active deformation front of the Himalaya.

Minimum AFT ages of the lowermost four samples from the Karnali section (i.e., KAR6, KAR3, KA441+KAR1), as well as the lowermost two samples from the Tinau section (BUT1+TIN1) all overlap at 2.1 $\pm 0.4 \mathrm{Ma}$ (Table 2), suggesting an onset of exhumation along 
the MFT around that time. In order to further constrain the exhumation history we attempted to invert the track-length distributions of the most deeply buried samples from the Karnali section for thermal history using the AFTSolve modelling procedure (Ketcham et al., 2000). Inverting track-length distributions in settings such as the one we study is far from straightforward and the resulting thermal histories should be considered with care. Firstly, the relatively short mean track lengths of the unreset samples (Table 3) indicate that the samples arrived in the basin with a relatively complex exhumation history that should be taken into account when modelling the post-depositional thermal history (e.g., Carter \& Gallagher, 2004). Secondly, the number of track lengths we were able to measure in any sample is low, diminishing the constraint on predicted thermal history. Thirdly, we are dealing with partially annealed samples characterised by a relatively large spread in ages and wide track-length distributions, indicative of variable pre-depositional thermal histories and/or variable resistance to annealing. In the Ketcham et al. (2000) modelling approach, these can be incorporated by defining multiple kinetic populations. Moreover, in detrital samples, thermal modelling should ideally be performed on a single age population in order to characterise a unique thermal history (e.g. Carrapa et al., 2006). However, since we measured track lengths on separate ${ }^{252} \mathrm{Cf}$-irradiated mounts and since we are working with relatively few track-length measurements, we refrained from separating our length measurements according to kinetic or age groups. We did, however, monitor the resistance to annealing of our samples by measuring etch-pit widths and found little variation in $D_{\text {par }}$ values, both within and between samples (Table 3).

Keeping the above caveats in mind, modelled thermal histories for four samples from the Karnali section are shown in Figure 11. We use the fact that samples were at the surface at the age of deposition as the principal constraint on these models, and use the source-area exhumation histories inferred for the shallow and lesser annealed samples to guide the predepositional histories of the deepest, most strongly annealed, samples. Because of the complications discussed above, none of the predicted thermal histories provide a very tight fit to the data, as indicated by relatively low values for the fit statistics. The different thermal histories are, however, remarkably consistent with each other; they all indicate heating from the time of deposition until $\sim 2 \mathrm{Ma}$, followed by a phase of thermal stability or slow cooling and a final phase of very rapid cooling from $\sim 0.3 \mathrm{Ma}$ onward. The final exhumation of basin strata is most tightly constrained by the deepest, most strongly annealed sample (i.e. KAR3), as expected. The maximum temperatures reached by the samples, as predicted by the inverse model, increase consistently with depth from 90-104 ${ }^{\circ} \mathrm{C}$ for KAR11 (2290 m depth) to 106- 
$115^{\circ} \mathrm{C}$ for KAR3 (4650 $\mathrm{m}$ depth), even though we modelled the samples individually. We chose not to use a combined inversion scheme (e.g., Gallagher et al., 2005) as this would imply imposing a constant geothermal gradient a priori. Predicted maximum paleotemperatures as a function of depth are shown in Figure 12.

Although the predicted maximum paleotemperatures are consistent with each other, they suggest a very low geothermal gradient of $7.3 \pm 3.8^{\circ} \mathrm{C} \mathrm{km}^{-1}\left(95 \%\right.$ confidence limit; $\left.\mathrm{r}^{2}=0.92\right)$ between $\sim 2300$ and $4650 \mathrm{~m}$ depth and imply a much higher geothermal gradient of $\sim 30{ }^{\circ} \mathrm{C}$ $\mathrm{km}^{-1}$ in the top $2 \mathrm{~km}$ of the section (Figure 12). The peak temperatures predicted for the lowermost three modelled samples are consistent with the $\sim 20{ }^{\circ} \mathrm{C} \mathrm{km}^{-1}$ geotherm inferred earlier from the depth of transition between unreset and partially annealed samples, but the predicted maximum paleotemperatures for the two upper samples are $15-25^{\circ} \mathrm{C}$ higher than expected. This discrepancy may reflect the difficulty of modelling the uppermost and least annealed samples. If the predicted paleotemperatures are valid, they require a strongly nonlinear geotherm within the Siwalik basin, which could suggest convective heat transport by fluids in the basin. Although independent paleotemperature indicators could be used to validate the model predictions, currently available vitrinite reflectance and illite crystallinity data (Huyghe et al., 2005) do not permit to discriminate between a linear or non-linear geotherm (Figure 12).

Irrespective of the predicted maximum paleotemperatures, the modelled thermal histories are readily explained within the tectonic setting of the frontal Siwalik belt. The initial postdepositional heating phase is clearly linked to post-depositional burial, the cessation of which at $\sim 2 \mathrm{Ma}$ would indicate onset of exhumation along the MFT. This timing is consistent with that inferred independently from the minimum AFT ages in the deepest samples, as well as with field observations of growth strata linked to the onset of movement along the MFT (Mugnier et al., 2004). Finally, the strong acceleration of cooling at $\sim 0.3 \mathrm{Ma}$ is consistent with passage of the rocks from the basal décollement onto the MFT ramp during exhumation (cf. Figure 3). Since the flat-ramp transition occurs at $~ 3500 \mathrm{~m}$ depth in the Karnali section (Figure 3), exhumation along a $30^{\circ}$ dipping ramp in $0.3 \mathrm{Myr}$ corresponds to a mean exhumation rate of $\sim 12 \mathrm{~mm} \mathrm{yr}^{-1}$ and a mean shortening rate of $\sim 20 \mathrm{~mm} \mathrm{yr}^{-1}$. These values are consistent with short-term rates of rock uplift and shortening along the MFT from tectonic geomorphology studies (Lavé \& Avouac, 2000; Mugnier et al., 2004), suggesting that the current shortening rates along the MFT have been maintained for at least the last $0.3 \mathrm{Myr}$.

One could argue that shortening at $\sim 20 \mathrm{~mm} \mathrm{yr}^{-1}$ could have taken place along the MFT since $2 \mathrm{Ma}$, implying $\sim 40 \mathrm{~km}$ of shortening along the MFT since its inception. However, such 
a scenario implies unrealistic depths of burial for samples at the base of the section. The dip of the décollement underlying the Siwaliks in western Nepal is 6-8 (Larson et al., 1999; Berger et al., 2004) and attaches to the ramp at a depth of $\sim 3500 \mathrm{~m}$. Shortening at $20 \mathrm{~mm} \mathrm{yr}^{-1}$ during 1.7 Myr (before reaching the ramp) implies maximum burial depths for samples at the base of the section of $7.1-8.3 \mathrm{~km}$, or maximum burial temperatures of $162-187{ }^{\circ} \mathrm{C}$ for a geothermal gradient of $20^{\circ} \mathrm{C} \mathrm{km}^{-1}$, largely sufficient to fully anneal all apatite in these samples regardless of composition. Even when adopting the non-linear geotherm suggested by the track-length inversions, maximum burial temperatures would be $126-135{ }^{\circ} \mathrm{C}$, sufficient to fully anneal fission tracks in apatites of the composition encountered in this study. In contrast to these predictions, none of the samples in our study are totally annealed, with even the deepest samples (KAR1, KA441) retaining 25\% of grains with AFT ages close to the depositional age (cf. Table 2; Figure 5). These results require either intermittent operation of the MFT since $2 \mathrm{Ma}$ or a recent increase in shortening rates along it. Preliminary thermal-kinematic forward modelling of the Karnali structure (Robert, 2005) suggests that intermittent operation of the MFT is most consistent with the thermochronological data presented here.

\section{CONCLUSIONS}

The low-temperature detrital AFT data presented here complement the detrital zircon data of Bernet et al. (2006) by highlighting spatial variations in source-area exhumation rates and by providing information on the post-depositional thermal and kinematic history of the Siwalik foreland basin. The most pertinent conclusions to be drawn from these data are the following:

Within the Surai section in central Nepal, the detrital AFT ages are inconsistent with the magneto-stratigraphic dating of this section as proposed by Appel et al. (1991) and recalibrated to the Cande \& Kent (1995) magnetic polarity timescale by Gautam \& Rösler (1999). In contrast, the data are consistent with more recent but unpublished magnetostratigraphic data (T.P. Ojha, pers. commun., 2003). Using depositional ages constrained by this magneto-stratigraphic framework, the Surai section AFT ages yield a constant lag time of $0.8 \pm 0.5 \mathrm{Myr}$, indicating rapid source-area exhumation rates of $\sim 1.8 \mathrm{~km} \mathrm{Myr}^{-1}$ since $\sim 7 \mathrm{Ma}$. In contrast, non-reset samples from the Karnali River section in western Nepal yield minimum lag-times that decrease from $\sim 4 \mathrm{Myr}$ at $\sim 7 \mathrm{Ma}$ to $\sim 2 \mathrm{Myr}$ at the top of the section, implying peak source-area exhumation rates in the order of $1.0-1.5 \mathrm{~km} \mathrm{Myr}^{-1}$. These spatial variations in source-area exhumation rates can be explained by either tectonic or climatic 
controls, or possibly a combination of the two. No indications for a significant increase in source-area exhumation rates over the last few Myr, as suggested by several authors, have been encountered. In contrast, lag times are conspicuously long for samples from the Upper Siwalik subgroup in the Surai section, suggesting an increasing influence of sedimentary recycling within the Siwaliks. Recycling is also indicated by the relatively old AFT age of present-day sediment in the Karnali River downstream of the Siwaliks, and by long lag times calculated from a published AFT dataset in the distal Bengal Fan.

Partially reset samples from the deeper parts of the sections provide insight into the kinematics of the Siwalik belt. In particular, they indicate onset of movement along the MFT at $\sim 2 \mathrm{Ma}$ and suggest that present-day shortening rates along the MFT have been operating for at least 0.3 Myr. The data suggest intermittent operation of the MFT between 2 and $0.3 \mathrm{Ma}$.

\section{Acknowledgments}

We thank Adam Szulc and Ananta Gajurel for valuable field assistance, and Jérôme Lavé for providing pilot samples BUT and MAR. Andy Carter (University College London) performed Cf-irradiations on the Karnali samples. Luis Martinez (Université Henri Poincaré, Nancy) provided vitrinite reflectance values for a number of samples. Detailed and constructive reviews by Doug Burbank, John Garver and Max Zattin helped to clarify the ideas contained in this paper. This study was supported by an INSU-CNRS Intérieur de la Terre programme grant to P. van der Beek and an INSU-CNRS Eclipse programme grant to P. Huyghe. M. Bernet was funded by a Marie Curie post-doctoral fellowship from the European Commission (contract HPMF-CT-2002-01779). 


\section{REFERENCES}

AGARWAL, R. P., PRASAD, D. N., SAMANTA, U., BERRY, C. M. \& SHARMA, J. (1994) Hydrocarbon potential of Siwalik Basin. In: Siwalik Foreland basin of Himalaya, Himalayan Geology, 15. Wadia Institute of Himalayan Geology, Dehra Dun, 301-320.

APPEL, E., RÖSLER, W. \& CORVINUS, G. (1991) Magnetostratigraphy of the MioPliocene Surai Khola Siwaliks in west Nepal. Geophysical Journal International 105, 191-198.

ARITA, K. \& GANZAWA, Y. (1997) Thrust tectonics and uplift of the Nepal Himalaya revealed from fission-track ages. Journal of Geography (Chigaku Zashi) 106, 156-167.

AVOUAC, J. P. (2003) Mountain building, erosion and the seismic cycle in the Nepal Himalaya. Advances in Geophysics 46, 1-79.

BARBARAND, J., CARTER, A., WOOD, I. \& HURFORD, A. (2003) Compositional and structural control of fission-track annealing in apatite. Chemical Geology 198, 107-137.

BEAUMONT, C., JAMIESON, R. A., NGUYEN, M. H. \& LEE, B. (2001) Himalayan tectonics explained by extrusion of a low-viscosity channel coupled to focused surface denudation. Nature 414, 738-742.

BERGER, A., JOUANNE, F., HASSANI, R. \& MUGNIER, J. L. (2004) Modelling the spatial distribution of present-day deformation in Nepal: how cylindrical is the Main Himalayan Thrust in Nepal? Geophysical Journal International 156, 94-114.

BERNET, M., BRANDON, M. T., GARVER, J. I. \& MOLITOR, B. (2004) Fundamentals of detrital zircon fission-track analysis for provenance and exhumation studies with examples from the European Alps. In: Detrital thermochronology - Provenance Analysis, Exhumation and Landscape Evolution of Mountain Belts (Ed. by Bernet, M. \& Spiegel, C.). Geological Society of America Special Paper 378, Boulder, Colorado, 25-36.

BERNET, M., VAN DER BEEK, P.A., PIK, R., HUYGHE, P. MUGNIER, J.L., LABRIN, E. \& SZULC, A.G. (2006) Miocene to Recent exhumation of the central Himalayas from detrital zircon fission-track analysis of Siwalik sediments, western Nepal. Basin Research (this issue).

BERNET, M., ZATTIN, M., GARVER, J. I., BRANDON, M. T. \& VANCE, J. A. (2001) Steady-state exhumation of the European Alps. Geology 29, 35-38.

BILHAM, R., LARSON, K., FREYMUELLER, J. \& PROJECT IDYLHIM MEMBERS. (1997) GPS measurements of present-day convergence across the Nepal Himalaya. Nature 386, 61-64. 
BLYTHE, A., BURBANK, D.W., CARTER, A., SCHMIDT, K.L. \& PUTKONEN, J. (2006) Plio-Quaternary exhumation history of the central Himalaya: 1. Apatite and zircon fissiontrack and apatite (U-Th)/He analyses. Tectonics, in press.

BOJAR, A.-V., FRITZ, H., NICOLESCU, S., BREGAR, M. \& GUPTA, R. P. (2005) Timing and mechanisms of Central Himalayan exhumation: discriminating between tectonic and erosion processes. Terra Nova 17, 427-433.

Bollinger, L., AVOUAC, J.-P., CATlos, E. J., HARRISON, T. M., GROVE, M., BEYSSAC, O., GOFFÉ, B. \& SAPKOTA, S. (2004) Thermal structure and exhumation history of the Lesser Himalaya in central Nepal. Tectonics 23, TC5015, doi:10.1029/2003TC001564.

BOOKHAGEN, B., THIEDE, R. C. \& STRECKER, M. R. (2005) Abnormal monsoon years and their control on erosion and sediment flux in the high, arid northwest Himalaya. Earth and Planetary Science Letters 231, 131-146.

BRANDON, M. T. (1996) Probability density plot for fission-track grain-age samples. Nuclear Tracks and Radiation Measurements 26, 663-676.

BRANDON, M. T., RODEN-TICE, M. \& GARVER, J. I. (1998) Late Cenozoic exhumation of the Cascadia accretionary wedge in the Olympic Mountains, northwest Washington State. Geological Society of America Bulletin 110, 985-1009.

BURBANK, D. W. (1992) Causes of recent Himalayan uplift deduced from deposited patterns in the Ganges basin. Nature 357, 680-683.

BURBANK, D. W., BECK, R. A. \& MULDER, T. (1996) The Himalayan Foreland. In: The Tectonic Evolution of Asia (Ed. by Yin, A. \& Harrison, T. M.). Cambridge University Press, New York, 149-188.

Burbank, D. W., Blythe, A. E., PUtKonen, J. K., PRATT-SitAula, B. A., GABET, E. J., OSKIN, M. E., BARROS, A. P. \& OJHA, T. P. (2003) Decoupling of erosion and precipitation in the Himalaya. Nature 426, 652-655.

BURBANK, D. W., DERRY, L. A. \& FRANCE-LANORD, C. (1993) Reduced Himalayan sediment production $8 \mathrm{Myr}$ ago despite an intensified monsoon. Nature 364, 48-50.

BURCHFIEL, B. C., ZHILIANG, C., HODGES, K. V., YUPING, L., ROYDEN, L. H., CHANGRONG, D. \& JIENE, X. (1992) The South Tibetan detachment system, Himalayan orogen: Extension contemporaneous with and parallel to shortening in a collisional mountain belt. Geological Society of America Special Paper 269, Boulder, Colorado. 
CAMPBELL, I. H., REINERS, P. W., ALLEN, C. M., NICOLESCU, S. \& UPADHYAY, R. (2005) $\mathrm{He}-\mathrm{Pb}$ double dating of detrital zircons from the Ganges and Indus Rivers: Implication for quantifying sediment recycling and provenance studies. Earth and Planetary Science Letters 237, 402-432.

CANDE, S. C. \& KENT, D. V. (1995) Revised calibration of the geomagnetic polarity timescale for the Late Cretaceous and Cenozoic. Journal of Geophysical Research 100, 6093-6096.

CARLSON, W. D., DONELICK, R. A. \& KETCHAM, R. A. (1999) Variability of apatite fission-track annealing kinetics: I. Experimental results. American Mineralogist 84, 1213 1223.

CARRAPA, B., STRECKER, M.R. \& SOBEL, E.R. (2006) Cenozoic orogenic growth in the Central Andes: Evidence from sedimentary rock provenance and apatite fission track thermochronology in the Fiambala Basin, southernmost Puna Plateau margin (NW Argentina). Earth and Planetary Science Letters, 247, 82-100.

CARTER, A. \& GALLAGHER, K. (2004) Characterizing the significance of provenance on the inference of thermal history models from apatite fission-track data - a synthetic data study. In: Detrital thermochronology - Provenance Analysis, Exhumation and Landscape Evolution of Mountain Belts (Ed. by Bernet, M. \& Spiegel, C.). Geological Society of America Special Paper 378, Boulder, Colorado, 7-24.

CATTIN, E. \& AVOUAC, J. P. (2000) Modeling mountain building and the seismic cycle in the Himalaya of Nepal. Journal of Geophysical Research 105, 13389-13408.

CEDERBOM, C., SINClAIR, H., SCHLUNEGGER, F. \& RAHN, M. (2004) Climateinduced rebound and exhumation of the European Alps. Geology 32, 709-712.

CERVENY, P. F., NAESER, N. D., ZEITLER, P. K., NAESER, C. W. \& JOHNSON, N. M. (1988) History of uplift and relief of the Himalaya during the past 18 million years: Evidence from fission-track ages of detrical zircons from sandstones of the Siwalik group. In: New Perspectives in Basin Analysis (Ed. by Kleinspehn, K. L. \& Paola, C.). Springer Verlag, New York, 43-61.

CHAMPEL, B., VAN DER BEEK, P. A., MUGNIER, J. L. \& LETURMY, P. (2002) Growth and lateral propagation of fault-related folds in the Siwaliks of western Nepal: Rates, mechanisms and geomorphic signature. Journal of Geophysical Research 107, 2111, doi:10.1029/2001JB000578.

CLIFT, P. \& GAEDICKE, C. (2002) Accelerated mass flux to the Arabian Sea during the middle to late Miocene. Geology 30, 207-210. 
CLIFT, P. D., CAMPBELL, I. H., PRINGLE, M. S., CARTER, A., ZHANG, X., HODGES, K. V., KHAN, A. A. \& ALLEN, C. M. (2004) Thermochronology of the modern Indus River bedload: New insight into the controls on the marine stratigraphic record. Tectonics 23, TC5013, doi:10.1029/2003TC001559.

COPELAND, P. \& HARRISON, T. M. (1990) Episodic rapid uplift in the Himalaya revealed by ${ }^{40} \mathrm{Ar} /{ }^{39} \mathrm{Ar}$ analysis of detrital K-feldspar and muscovite, Bengal fan. Geology 18, $354-$ 357.

CORRIGAN, J. D. \& CROWLEY, K. D. (1990) Fission-track analysis of detrital apatites from sites 717 and 718, Leg 116, Central Indian Ocean. In: Proceedings Ocean Drilling Program 116B, 75-83.

CORVINUS, G. \& RIMAL, L. N. (2001) Biostratigraphy and geology of the Neogene Siwalik Group of the Surai Khola and Rato Khola areas in Nepal. Palaeogeography, Palaeoclimatology, Palaeoecology 165, 251-279.

DECELLES, P. G., GEHRELS, G. E., QUADE, J., OJHA, T. P., KAPP, P. A. \& UPRETI, B. N. (1998) Neogene foreland basin deposits, erosional unroofing, and the kinematic history of the Himalayan fold-thrust belt, western Nepal. Geological Society of America Bulletin 110, 2-21.

DECElleS, P. G., ROBINSON, D. M., QUADE, J., OJHA, T. P., GARZIONE, C. N., COPELAND, P. \& UPRETI, B. N. (2001) Stratigraphy, structure, and tectonic evolution of the Himalayan fold-thrust belt in western Nepal. Tectonics 20, 487-509.

DODSON, M. H. (1973) Closure temperature in cooling geochronological and petrological systems. Contributions to Mineralogy and Petrology 40, 259-274.

FINLAYSON, D. P., MONTGOMERY, D. R. \& HALLET, B. (2002) Spatial coincidence of rapid inferred erosion with young metamorphic massifs in the Himalayas. Geology 30 , $219-222$.

FRANCE-LANORD, C. \& DERRY, L. A. (1997) Organic carbon burial forcing of the carbon cycle from Himalayan erosion. Nature 390, 65-67.

GALBRAITH, R. F. (1990) The radial plot: Graphical assessment of spread in ages. Nuclear Tracks and Radiation Measurements 17, 207-214.

GALBRAITH, R. F. \& LASLETT, G. M. (1993) Statistical models for mixed fission track ages. Nuclear Tracks and Radiation Measurements 21, 459-470.

GALLAGHER, K., BROWN, R. \& JOHNSON, C. (1998) Fission track analysis and its applications to geological problems. Annual Review of Earth and Planetary Sciences 26, $519-572$ 
GAllagher, K., STEPHENSON, J., BROWN, R., HOLMES, C. \& FITZGERALD, P. (2005) Low temperature thermochronology and modeling strategies for multiple samples 1: Vertical profiles. Earth and Planetary Science Letters 237(1-2), 193-208.

GARVER, J. I., BRANDON, M. T., RODEN-TICE, M. \& KAMP, P. J. J. (1999) Exhumation history of orogenic highlands determined by detrital fission-track thermochronology. In: Exhumation Processes: Normal Faulting, Ductile Flow and Erosion (Ed. by Ring, U., Brandon, M. T., Willett, S. D. \& Lister, G. S.). Geological Society, London, Special Publication 154, 283-304.

GAUTAM, P. \& APPEL, E. (1994) Magnetic-polarity stratigraphy of Siwalik Group sediments of Tinau Khola section in west central Nepal, revisited. Geophysical Journal International 117, 223-234.

GAUTAM, P. \& FUJIWARA, Y. (2000) Magnetic polarity stratigraphy of Siwalik Group sediments of Karnali River section in western Nepal. Geophysical Journal International 142, 812-824.

GAUTAM, P. \& RÖSLER, W. (1999) Depositional chronology and fabric of Siwalik Group sediments in central Nepal from magnetostratigraphy and magnetic anisotropy. Journal of Asian Earth Sciences 17, 659-682.

GUILlOT, S., HODGES, K., LE FORT, P. \& PÊCHER, A. (1994) New constraints on the age of the Manaslu leucogranite: Evidence for episodic tectonic denudation in the central Himalayas. Geology 22, 559-562.

GUPTA, S. (1997) Himalayan drainage patterns and the origin of fluvial megafans in the Ganges foreland basin. Geology 25, 11-14.

HARRISON, T. M., COPELAND, P., HALL, S. A., QUADE, J., BURNER, S., OJHA, T. P. \& KIDD, W. S. F. (1993) Isotopic preservation of Himalayan/Tibetan uplift, denudation, and climatic histories in two molasse deposits. Journal of Geology 100, 157-173.

HAY, W. W. (1998) Detrital sediment fluxes from continents to oceans. Chemical Geology 145, 287-323.

HODGES, K. V. (2000) Tectonics of the Himalaya and southern Tibet from two perspectives. Geological Society of America Bulletin 112, 324-350.

HODGES, K. V., HURTADO, J. M. \& WHIPPLE, K. X. (2001) Southward extrusion of Tibetan crust and its effect on Himalayan tectonics. Tectonics 20, 799-809.

HODGES, K. V., PARRISH, R. R. \& SEARLE, M. P. (1996) Tectonic evolution of the central Annapurna Range, Nepalese Himalayas. Tectonics 15, 1264-1291. 
HODGES, K. V., WOBUS, C. W., RUHL, K., SCHILDGEN, T. \& WHIPPLE, K. X. (2004) Quaternary deformation, river steepening, and heavy precipitation at the front of the Higher Himalayan ranges. Earth and Planetary Science Letters 220, 379-389.

HOORN, C., OHJA, T. \& QUADE, J. (2000) Palynological evidence for vegetation development and climatic change in the Sub-Himalayan Zone (Neogene, Central Nepal). Palaeogeography, Palaeoclimatology, Palaeoecology 163, 133-161.

HURFORD, A. J. (1990) International union of geological sciences subcommission on geochronology recommendation for the standardization of fission track dating calibration and data reporting. Nuclear Tracks and Radiation Measurements 17, 233-236.

HUSSON, L., MUGNIER, J. L., LETURMY, P. \& VIDAL, G. (2004) Kinematics and sedimentary balance of the Subhimalayan zone, western Nepal. In: Thrust Tectonics and Petroleum Systems (Ed. by McClay, K. R.). American Association of Petroleum Geologists Memoir 82, 115-130.

HUYGHE, P., GALY, A., MUGNIER, J. L. \& FRANCE-LANORD, C. (2001) Propagation of the thrust system and erosion in the Lesser Himalaya: Geochemical and sedimentological evidence. Geology 29, 1007-1010.

HUYGHE, P., MUGNIER, J. L., GAJUREL, A. P. \& DELCAILlAU, B. (2005) Tectonic and climatic control of the changes in the sedimentary record of the Karnali River section (Siwaliks of Western Nepal). The Island Arc 14, 311-327.

JAIN, A. K., KUMAR, D., SINGH, S., KUMAR, A. \& LAL, N. (2000) Timing, quantification and tectonic modelling of Pliocene-Quaternary movements in the NW Himalaya: evidence from fission track dating. Earth and Planetary Science Letters 179, 437-451.

JOUANNE, F., MUGNIER, J. L., GAMOND, J. F., LE FORT, P., PANDEY, M. R., BOLlingER, L., FlOUZAT, M. \& AVOUAC, J. P. (2004) Current shortening across the Himalayas of Nepal. Geophysical Journal International 157, 11-14.

KETCHAM, R. A., DONELICK, R. A. \& CARLSON, W. D. (1999) Variability of apatite fission-track annealing kinetics: III. Extrapolation to geological time scales. American Mineralogist 84, 1235-1255.

KETCHAM, R. A., DONELICK, R. A. \& DONELICK, M. B. (2000) AFTSolve: A program for multi-kinetic modeling of apatite fission-track data. Geological Materials Research 2, http://gmr.minsocam.org/Papers/v2/v2n1/v2n1abs.html. 
LARSON, K. M., BÜRGMANN, R., BILHAM, R. \& FREYMUELLER, J. T. (1999) Kinematics of the India-Eurasia collision zone from GPS measurements. Journal of Geophysical Research 104, 1077-1093.

LAVÉ, J. \& AVOUAC, J. P. (2000) Active folding of fluvial terraces across the Siwaliks Hills (Himalayas of central Nepal). Journal of Geophysical Research 105, 5735-5770.

LAVÉ, J. \& AVOUAC, J. P. (2001) Fluvial incision and tectonic uplift across the Himalayas of central Nepal. Journal of Geophysical Research 106, 25561-25593.

LOCKE, B. D. \& GARVER, J. I. 2005. Thermal evolution of the eastern Serranía del Interior foreland fold and thrust belt, northeastern Venezuela, based on apatite fission-track analyses. In: Caribbean-South American plate interactions, Venezuela (Ed. by Avé Lallemant, H. G. \& Sisson, V. B.). Geological Society of America Special Paper 394, $315-328$.

LYON-CAEN, H. \& MOLNAR, P. (1985) Gravity anomalies, flexure of the Indian plate and the structure, support and evolution of the Himalaya and Ganga Basin. Tectonics 4, 513538.

MEIGS, A. J., BURBANK, D. W. \& BECK, R. A. (1995) Middle-Late Miocene (> 10 Ma) formation of the Main Boundary Thrust in the western Himalaya. Geology 23, 423-426.

MÉTIVIER, F., GAUDEMER, Y., TAPPONIER, P. \& KLEIN, M. (1999) Mass accumulation rates in Asia during the Cenozoic. Geophysical Journal International 137, 280-318.

MUGNIER, J. L., CHALARON, E., MASClE, G., PRADIER, B. \& HÉRAIL, G. (1995) Structural and thermal evolution of the Siwaliks of western Nepal. Journal of Nepal Geological Society 11, 171-178.

MUGNIER, J. L. \& HUYGHE, P. (2006) The Ganges Basin geometry records a pre-15 Ma lithospheric isostatic rebound of the Himalaya. Geology, 34, 445-448.

MUGNIER, J. L., HUYGHE, P., LETURMY, P. \& JOUANNE, F. (2004) Episodicity and rates of thrust sheet motion in the Himalayas (western Nepal). In: Thrust Tectonics and Petroleum Systems (Ed. by McClay, K. C.). American Association of Petroleum Geologists Memoir 82, 1-24.

MUGNIER, J. L., LETURMY, P., MASClE, G., HUYGHE, P., CHALARON, E., VIDAL, G., HUSSON, L. \& DELCAILlAU, B. (1999) The Siwaliks of western Nepal: I Geometry and kinematics. Journal of Asian Earth Sciences 17, 629-642.

MUGNIER, J. L., MASCLE, G. \& FAUCHER, T. (1993) Structure of the Siwaliks of western Nepal: An intracontinental accretionary prism. International Geology Reviews 35, 32-47. 
NAKAYAMA, K. \& ULAK, P. D. (1999) Evolution of fluvial style in the Siwalik Group in the foothills of the Nepal Himalaya. Sedimentary Geology 125, 205-224.

QUADE, J., CATER, J. M. L., OJHA, T. P., ADAM, J. \& HARRISON, T. M. (1995) Late Miocene environmental change in Nepal and the northern Indian subcontinent: Stable isotopic evidence from paleosols. Geological Society of America Bulletin 107, 1381-1397.

RAYMO, M. W. \& RUDDIMAN, W. F. (1992) Tectonic forcing of late Cenozoic climate. Nature 359, 117-122.

ROBERT, X. (2005) Analyse thermochronologique des sédiments Siwaliks : implications pour la séquence d'activité des failles et la mécanique du prisme frontal de l'Himalaya, Unpublished MSc. Thesis, Université Joseph Fourier, Grenoble, 36 pp.

ROBINSON, D. M., DECELLES, P. G., PATCHETT, P. J. \& GARZIONE, C. N. (2001) The kinematic evolution of the Nepalese Himalaya interpreted from $\mathrm{Nd}$ isotopes. Earth and Planetary Science Letters 192, 507-521.

ROHRMAN, M., ANDRIESSEN, P. A. M. \& VAN DER BEEK, P. A. (1996) The relationship between basin and margin thermal evolution assessed by fission track thermochronology: an application to offshore southern Norway. Basin Research 8, 45-63.

STEWART, R. J. \& BRANDON, M. T. (2004) Detrital-zircon fission-track ages for the "Hoh Formation": Implications for late Cenozoic evolution of the Cascadia subduction wedge. Geological Society of America Bulletin 116, 60-75.

SUMMERFIELD, M. A. \& HULTON, N. J. (1994) Natural controls of fluvial denudation rates in major world drainage basins. Journal of Geophysical Research 99, 13871-13883.

SZULC, A. G., NAJMAN, Y., SINCLAIR, H., PRINGLE, M., BICKLE, M., CHAPMAN, H., GARZANTi, E., ANDO, S., HUYGHe, P., MUGNiER, J. L., OJHA, T. P. \& DECELLES, P. G. (2006) A detrital investigation of three Siwalik sections in the Nepalese Himalaya. Basin Research (this issue).

THIEDE, R. C., BOOKHAGEN, B., ARROWSMITH, J. R., SOBEL, E. R. \& STRECKER, M. R. (2004) Climatic control on rapid exhumation along the Southern Himalayan Front. Earth and Planetary Science Letters 222, 791-806.

TOKUOKA, T., TAKAYASU, K., HISATOMI, K., YAMASAKI, H., TANAKA, S., KONOMATSU, M., SAH, R. S. \& RAI, S. M. (1990). Stratigraphy and geologic structures of the Churia (Siwalik) Group in the Tinau Khola - Binai Khola area, west central Nepal. Faculty of Science, Shimane University, Matsue, Japan, 71-88. 
VAN DER BEEK, P. A., CHAMPEL, B. \& MUGNIER, J. L. (2002) Control of detachment dip on drainage development in regions of active fault-propagation folding. Geology 30, 471-474.

VANCE, D., BICKLE, M., IVY-OCHS, S. \& KUBIK, P. W. (2003) Erosion and exhumation in the Himalaya from cosmogenic isotope inventories of river sediments. Earth and Planetary Science Letters 206, 237-633.

VANNAY, J.-C., GRASEMANN, B., RAHN, M., FRANK, W., CARTER, A., BAUDRAZ, V. \& COSCA, M. (2004) Miocene to Holocene exhumation of metamorphic crustal wedges in the NW Himalaya: Evidence for tectonic extrusion coupled to fluvial erosion. Tectonics 23, TC1014, doi:10.1029/2002TC001429.

WHITE, N. M., PRINGLE, M., GARZANTI, E., BICKLE, M., NAJMAN, Y., CHAPMAN, H. \& FRIEND, P. (2002) Constraints on the exhumation and erosion of the High Himalayan Slab, NW India, from foreland basin deposits. Earth and Planetary Science Letters 195, 29-44.

WILLIAMSON, J.H. (1968) Least squares fitting of a straight line. Canadian Journal of Physics, 46, 1845-1847.

WOBUS, C. W., HODGES, K. V. \& WHIPPLE, K. X. (2003) Has focused denudation sustained active thrusting at the Himalayan topographic front? Geology 31, 861-864.

YIN, A. \& HARRISON, T. M. (2000) Geologic Evolution of the Himalayan-Tibetan Orogen. Annual Review of Earth and Planetary Sciences 28, 211-280.

ZHAO, W., NELSON, K. D. \& PROJECT INDEPTH TEAM. (1993) Deep seismic reflection evidence for continental underthrusting beneath southern Tibet. Nature 366, 557-559. 


\section{FIGURE CAPTIONS}

Figure 1. (a) Concept of detrital thermochronology and principal differences between detrital apatite and detrital zircon fission-track thermochronology. Samples collected at stratigraphic horizons 1-4 record integrated exhumation rates between the time they passed through the closure temperature $\left(t_{c}\right)$ and the time they arrived at the surface $\left(t_{e}\right) \cdot t_{d}$ is time of deposition; it is generally assumed that $t_{d}=t_{e}$. Lag time equals $t_{c}-t_{d}\left(=t_{c}-t_{e}\right)$. Subscripts $(A)$ and $(Z)$ refer to the closure temperatures for the apatite and zircon fission-track systems, respectively; PAZ $=$ Partial Annealing Zone. Because of the relatively low closure temperature of the apatite fission-track system, samples may be partially or totally reset within the sedimentary basin. Modified from Garver et al. (1999). (b and c) Synthetic model for samples collected from an exhumed basin. Samples are initially exhumed from their source areas at a rate of $1 \mathrm{~km} \mathrm{Myr}^{-1}$ and deposited in the basin from $16 \mathrm{Ma}$ onward. A single source terrain with uniform exhumation rates is considered here. Basin sedimentation rates are constant between 16 and 5 $\mathrm{Ma}$ at $500 \mathrm{~m} \mathrm{My}^{-1}$; the basin is exhumed from $5 \mathrm{Ma}$ onward. For simplicity, a constant $20^{\circ} \mathrm{C}$ $\mathrm{km}^{-1}$ geotherm is assumed for both the source area and the sedimentary basin. Predicted pattern of AFT ages as a function of maximum stratigraphic depth is shown in (b), for highly retentive (HR) and low-retentive (LR) apatites, respectively. AFT ages are calculated using the forward model of Ketcham et al. (2000) using the thermal histories depicted in (c) and annealing kinetics characterised by $\mathrm{D}_{\text {par }}$ values of $2.0 \mu \mathrm{m}$ and $1.0 \mu \mathrm{m}$ for HR and LR apatites, respectively (cf. Carlson et al., 1999; Barbarand et al., 2003). Shaded box in (b) represents apatite PAZ. See text for discussion.

Figure 2. Simplified geological map of Nepal showing major tectonostratigraphic units and faults (modified from DeCelles et al., 2001). Locations of sampled sections (KAR: Karnali; SUR: Surai; TIN: Tinau) and modern-day river samples are indicated. Inset shows location of Nepal.

Figure 3. Balanced cross section along the Karnali River showing sample locations and relationship with local structure. Modified from Mugnier et al. (1999).

Figure 4. Plot of AFT central age against depth for all samples. Stratigraphic ages for the three sections (after Gautam and Fujiwara (2000) for the Karnali section; T.P. Ojha (pers. commun. 2003) for the Surai and Tinau sections) are also indicated. 
Figure 5. Radial plots (Galbraith, 1990; left) and probability density functions (right) for a number of representative samples. Within the radial plots, thin black lines indicate the different peak ages recognised within the sample; thick shaded lines indicate the depositional age. $N$ : number of grains represented; D: age dispersion (Galbraith \& Laslett, 1993). Bars within probability density plots are histograms of single-grain age distribution; thick shaded line is single-grain age probability-density function of the entire population (Brandon, 1996); thin black lines are modelled probability-density functions for the fitted age populations.

Figure 6. Plot of AFT central ages from the Surai section against the depositional age of the samples, using either the magnetostratigraphy of Appel et al. (1991), as recalibrated by Gautam \& Rösler (1999), or the unpublished magnetostratigraphic data of T.P. Ojha (pers. commun., 2003). As all samples contain a single age population, the AFT central age is meaningful, and as these AFT ages represent a source-area denudation signal, they should be older than the depositional age. See text for discussion.

Figure 7. Main panel shows plot of AFT central ages (black diamonds) and P1 ages (i.e., peak age of the youngest population; white squares) against depth for samples from the Karnali River section. Small panels show track-length histograms for Karnali section samples (N: number of tracks lengths measured; MTL: Mean track length, $\sigma$ : standard deviation).

Figure 8. Lag-time plot showing AFT age against depositional age of non-reset samples from the Surai, Karnali and Tinau sections. For samples that contain a single age population (e.g. Surai and lower three Karnali samples), the central age is plotted; for samples with multiple age components, only the youngest age peak (P1) is reproduced. Diagonal lines represent constant lag times as indicated.

Figure 9. Modelled peak exhumation rates as a function of time calculated from AFT and ZFT lag times observed in the Karnali and Surai section samples. A modified version of the 1D model of Brandon et al. (1998) is used in the calculation; closure temperature is estimated following Dodson (1973) using the kinetic parameters estimated from annealing experiments by Brandon et al. (1998); AFT: $E_{a}=186.4 \mathrm{~kJ} \mathrm{~mol}^{-1}, D_{0} / a^{2}=3.64 \times 10^{10} \mathrm{~s}^{-1}$; ZFT: $E_{a}=208.2 \mathrm{~kJ}$ $\mathrm{mol}^{-1}, D_{0} / a^{2}=3.70 \times 10^{6} \mathrm{~s}^{-1}$. Other parameter values used in the model: surface temperature $T_{S}$ 
$=20{ }^{\circ} \mathrm{C}$, initial geothermal gradient $G=20{ }^{\circ} \mathrm{C} \mathrm{km}^{-1}$, model thickness $L=25 \mathrm{~km}$, thermal diffusivity $\kappa=25 \mathrm{~km}^{2} \mathrm{Myr}^{-1}$. Uncertainties in predicted exhumation rate are propagated from $2 \sigma$ uncertainties in peak or central ages. See text for discussion.

Figure 10. Lag-time plot for the Bengal Fan data of Corrigan \& Crowley (1990). The dataset was treated in the same manner as our own data (Table 4); the plot shows the P1 age peaks. Diagonal lines represent constant lag times as indicated. Compare to Figure 8.

Figure 11. Representative thermal histories for partially reset samples from the Karnali River section. Thick line is best-fit model; shaded area corresponds to acceptable model fits. For each sample, the legend provides the measured AFT age, mean track length (MTL) and standard deviation of the track-length distribution $(\sigma)$, compared to the best-fit model predictions in parentheses. Also quoted is the $\mathrm{D}_{\text {par }}$ value used in the inversion. The inversion used a constrained random search with 10,000 iterations to find a best-fit solution (cf. Ketcham et al., 2000); model fit to the data is given by the KS statistic for the comparison of modelled and observed track-length distributions, and a goodness-of-fit criterion analogous to the KS statistic for the observed and predicted AFT age. For clarity, the pre-depositional cooling of samples KAR3, 6, and 7 has been omitted; this part of the thermal history is essentially unconstrained by the data.

Figure 12. Maximum paleotemperature reached by the partially annealed samples from the Karnali River section, as predicted by the AFTSolve inversions, plotted as a function of stratigraphic depth. Dots indicate maximum temperature of best-fit inversion; error bars correspond to maximum and minimum peak temperatures allowed by the 'acceptable' model fits (cf. Figure 11). Shown for comparison are the maximum paleotemperatures inferred from illite crystallinity (IC; Huyghe et al., 2005) and vitrinite reflectance $\left(\mathrm{R}_{0}\right.$; L. Martinez, pers. commun. 2003) data in the upper part of the Karnali section, and the depth of the transition from unreset to partially reset samples and its associated temperature range. The peak temperatures from AFT inversions are consistent with a geothermal gradient of $7.3 \pm 3.8^{\circ} \mathrm{C}$ $\mathrm{km}^{-1}\left(95 \%\right.$ confidence limit; $\left.\mathrm{r}^{2}=0.92\right)$ between $\sim 2300$ and $\sim 4600 \mathrm{~m}$ depth and require a gradient of $\sim 30{ }^{\circ} \mathrm{C} \mathrm{km}^{-1}$ above that depth range. A linear $20{ }^{\circ} \mathrm{C} \mathrm{km}^{-1}$ gradient is plotted for comparison. 
Table 1a. Detrital apatite fission-track data from the Siwaliks of western-central Nepal

\begin{tabular}{|c|c|c|c|c|c|c|c|c|c|c|c|c|}
\hline Sample & $\begin{array}{c}\text { Stratigraphic } \\
\text { age } \\
(\mathrm{Ma}) \\
\end{array}$ & $\begin{array}{c}\text { Stratigraphic } \\
\text { depth } \\
\text { (m) }\end{array}$ & $\mathbf{N}$ & $\begin{array}{c}\rho_{\mathrm{s}} \\
\left(\times 10^{6} \mathrm{~cm}^{-2}\right)\end{array}$ & $\mathbf{N}_{\mathbf{s}}$ & $\begin{array}{c}\rho_{\mathbf{i}} \\
\left(\times 10^{6} \mathrm{~cm}^{-2}\right)\end{array}$ & $\mathbf{N}_{\mathbf{i}}$ & $\begin{array}{c}\rho_{\mathbf{d}} \\
\left(\times 10^{6} \mathrm{~cm}^{-2}\right)\end{array}$ & $\mathbf{N}_{\mathbf{d}}$ & $\begin{array}{c}\mathbf{P}\left(\chi^{2}\right) \\
(\%)\end{array}$ & $\begin{array}{c}\text { D } \\
(\%)\end{array}$ & $\begin{array}{c}\text { Age } \pm 2 \sigma \\
(\mathrm{Ma})\end{array}$ \\
\hline \multicolumn{13}{|l|}{ Karnali Section } \\
\hline KAR14 & $2.8 \pm 0.3$ & 925 & 41 & 0.087 & 303 & 1.416 & 4913 & 0.555 & 14306 & 2 & 25 & $6.0 \pm 1.0$ \\
\hline KA 30 & $4.3 \pm 0.2$ & 1420 & 41 & 0.121 & 434 & 1.028 & 3695 & 0.374 & 15841 & 46 & 28 & $7.4 \pm 1.2$ \\
\hline KAR13 & $5.2 \pm 0.1$ & 1720 & 16 & 0.130 & 165 & 1.359 & 1725 & 0.551 & 14306 & 4 & 29 & $9.0 \pm 2.2$ \\
\hline KAR12 & $6.0 \pm 0.1$ & 1950 & 44 & 0.122 & 454 & 1.359 & 5041 & 0.554 & 14306 & 1 & 20 & $8.9 \pm 1.2$ \\
\hline KA 34 & $6.4 \pm 0.1$ & 2070 & 63 & 0.116 & 694 & 0.807 & 4847 & 0.377 & 15841 & 68 & 24 & $9.5 \pm 1.0$ \\
\hline KAR11 & $6.9 \pm 0.1$ & 2290 & 51 & 0.101 & 435 & 0.921 & 3976 & 0.553 & 14306 & 59 & 6 & $10.5 \pm 1.2$ \\
\hline KA 36 & $7.5 \pm 0.1$ & 2510 & 11 & 0.118 & 93 & 0.674 & 531 & 0.378 & 15841 & 44 & 12 & $11.5 \pm 2.8$ \\
\hline KAR10 & $8.1 \pm 0.1$ & 2630 & 59 & 0.073 & 365 & 1.049 & 5235 & 0.514 & 14306 & 2 & 20 & $6.9 \pm 0.8$ \\
\hline KAR9 & $9.0 \pm 0.1$ & 2915 & 49 & 0.147 & 598 & 1.398 & 5704 & 0.550 & 14306 & 62 & 17 & $10.1 \pm 1.2$ \\
\hline KAR7 & $10.9 \pm 0.1$ & 3710 & 56 & 0.115 & 546 & 1.271 & 6021 & 0.549 & 14306 & 7 & 15 & $8.5 \pm 1.0$ \\
\hline KAR6 & $12.1 \pm 0.1$ & 3980 & 48 & 0.071 & 289 & 0.858 & 3469 & 0.544 & 14306 & 1 & 31 & $8.2 \pm 1.4$ \\
\hline KAR3 & $14.1 \pm 0.1$ & 4650 & 51 & 0.032 & 139 & 0.804 & 3469 & 0.545 & 14306 & $<<1$ & 57 & $4.0 \pm 1.0$ \\
\hline KA 441 & $15.9 \pm 0.1$ & 5265 & 44 & 0.004 & 383 & 0.060 & 6344 & 0.370 & 15841 & $<<1$ & 76 & $4.0 \pm 1.0$ \\
\hline \multicolumn{13}{|c|}{ Tinau Khola Section } \\
\hline TIN13 & $6.1 \pm 0.2$ & 2010 & 44 & 0.108 & 243 & 1.105 & 2499 & 0.735 & 17622 & 93.2 & $<<1$ & $11.2 \pm 2.0$ \\
\hline TIN8 & $7.2 \pm 0.2$ & 2504 & 54 & 0.097 & 403 & 0.976 & 4076 & 0.735 & 17622 & 26.8 & 22 & $11.2 \pm 1.8$ \\
\hline BUT4 & $9.1 \pm 0.1$ & 2811 & 29 & 0.209 & 529 & 2.847 & 7204 & 0.512 & 15671 & 22.0 & 23 & $6.5 \pm 0.8$ \\
\hline TIN5 & $10.3 \pm 0.2$ & 3343 & 48 & 0.023 & 84 & 0.406 & 1493 & 0.735 & 17622 & 98.7 & $<<1$ & $6.4 \pm 1.6$ \\
\hline BUT3 & $10.3 \pm 0.2$ & 3343 & 29 & 0.209 & 487 & 3.328 & 7774 & 0.512 & 15671 & $<<1$ & 42 & $6.0 \pm 1.2$ \\
\hline TA18A & $11.0 \pm 0.1$ & 3694 & 39 & 0.054 & 160 & 0.732 & 2154 & 0.519 & 13449 & 35.0 & 49 & $6.1 \pm 1.6$ \\
\hline TA17 & $11.3 \pm 0.2$ & 3810 & 34 & 0.065 & 178 & 0.970 & 2672 & 0.519 & 13449 & 60.9 & 13 & $6.0 \pm 1.0$ \\
\hline BUT1 & $12.0 \pm 0.3$ & 3976 & 9 & 0.137 & 58 & 3.266 & 1382 & 0.512 & 15671 & 1.2 & 32 & $4.5 \pm 1.6$ \\
\hline TIN1 & $12.0 \pm 0.3$ & 3976 & 24 & 0.047 & 53 & 0.585 & 662 & 0.735 & 12709 & 51.3 & $<<1$ & $9.1 \pm 2.8$ \\
\hline \multicolumn{13}{|c|}{ Surai Khola Section } \\
\hline SUR20 & $1.0 \pm 0.5$ & 417 & 25 & 0.416 & 215 & 6.367 & 3292 & 0.546 & 166698 & 96 & $<<1$ & $6.2 \pm 1.0$ \\
\hline SUR17 & $4.0 \pm 0.2$ & 1347 & 53 & 0.021 & 193 & 0.443 & 4101 & 0.545 & 166698 & 84 & 1 & $4.4 \pm 0.6$ \\
\hline SUR16 & $4.0 \pm 0.2$ & 1397 & 63 & 0.036 & 192 & 0.829 & 4393 & 0.544 & 166698 & 99 & 1 & $4.1 \pm 0.6$ \\
\hline SUR15 & $4.8 \pm 0.3$ & 1825 & 38 & 0.037 & 106 & 0.597 & 1696 & 0.546 & 166698 & 98 & 1 & $5.9 \pm 1.2$ \\
\hline SUR1 & $4.9 \pm 0.1$ & 1932 & 20 & 0.157 & 69 & 1.613 & 709 & 0.543 & 166698 & 100 & $<<1$ & $9.2 \pm 2.4$ \\
\hline SUR8 & $7.0 \pm 0.1$ & 2727 & 68 & 0.031 & 179 & 0.386 & 2220 & 0.543 & 166698 & 100 & $<<1$ & $7.6 \pm 1.2$ \\
\hline
\end{tabular}


Table 1b. Detrital apatite fission-track data from modern river sands, western-central Nepal.

\begin{tabular}{|c|c|c|c|c|c|c|c|c|c|c|c|c|c|}
\hline Sample & River & Long. & Lat. & $\mathbf{N}$ & $\begin{array}{c}\rho_{\mathrm{s}} \\
\left(\times 10^{6} \mathrm{~cm}^{-2}\right)\end{array}$ & $\mathbf{N}_{\mathrm{s}}$ & $\begin{array}{c}\rho_{\mathbf{i}} \\
\left(\times 10^{6} \mathrm{~cm}^{-2}\right) \\
\end{array}$ & $\mathbf{N}_{\mathrm{i}}$ & $\begin{array}{c}\rho_{\mathbf{d}} \\
\left(\times 10^{6} \mathrm{~cm}^{-2}\right) \\
\end{array}$ & $\mathbf{N}_{\mathbf{d}}$ & $\begin{array}{c}\mathbf{P}\left(\chi^{2}\right) \\
(\%)\end{array}$ & $\begin{array}{c}\text { D } \\
(\%)\end{array}$ & $\begin{array}{c}\text { Age } \pm 2 \sigma \\
(\mathrm{Ma})\end{array}$ \\
\hline MAR6 & Trisuli & $84^{\circ} 39^{\prime}$ & $27^{\circ} 46^{\prime}$ & 32 & 0.025 & 74 & 1.308 & 3822 & 0.572 & 11674 & 55.3 & 15 & $1.9 \pm 0.4$ \\
\hline MAR10 & Marsyandi & $84^{\circ} 32^{\prime}$ & $27^{\circ} 52^{\prime}$ & 54 & 0.016 & 85 & 0.896 & 4808 & 0.572 & 11674 & 65.8 & 2 & $1.7 \pm 0.4$ \\
\hline
\end{tabular}

All age determinations were performed by E. Labrin; with $\zeta=346.6 \pm 6.3$ for glass dosimeter NBS962; all ages are reported as central ages (Galbraith \& Laslett,

1993). $\mathrm{N}=$ number of grains counted; $\rho_{\mathrm{s}}=$ spontaneous track density; $\rho_{\mathrm{i}}=$ induced track density; $\rho_{\mathrm{d}}=$ dosimeter track density; $\mathrm{N}_{\mathrm{s}}, \mathrm{N}_{\mathrm{i}}, \mathrm{N}_{\mathrm{d}}=$ number of tracks counted to determine the reported track densities. For irradiations with significant ( $>3 \%$ ) axial gradients in neutron fluence (as monitored by the dosimeters), $\rho_{\mathrm{d}}$ is interpolated between dosimeter values. $\mathrm{P}\left(\chi^{2}\right)=$ Chi-square probability that the single grain ages represent one population; $\mathrm{D}=$ age dispersion. Stratigraphic age and depth are calculated from the magnetostratigraphic data of Gautam and Fujiwara (2000) for the Karnali section, and from unpublished data by T.P. Ojha (pers. commun. 2003) for the Surai and Tinau sections. 
Table 2. Results of binomial peak-age fitting for samples containing multiple age populations.

\begin{tabular}{|c|c|c|c|c|c|c|}
\hline Sample & $\begin{array}{c}\text { Strat. age } \\
\text { (Ma) }\end{array}$ & $\mathbf{N}$ & $\begin{array}{c}\text { Age range } \\
\text { (Ma) }\end{array}$ & $\begin{array}{c}\mathbf{P 1} \pm 2 \sigma \\
(\mathrm{Ma})\end{array}$ & $\begin{array}{c}\mathbf{P} 2 \pm 2 \sigma \\
(\mathrm{Ma})\end{array}$ & $\begin{array}{c}\mathbf{P} 3 \pm 2 \sigma \\
(\mathrm{Ma})\end{array}$ \\
\hline \multicolumn{7}{|c|}{ Karnali Section } \\
\hline KAR14 & 2.8 & 41 & $2.7-25.3$ & $\begin{array}{c}5.0 \pm 1.1 \\
(74)\end{array}$ & $\begin{array}{c}8.2 \pm 4.3 \\
\quad(22)\end{array}$ & $\begin{array}{c}14.1 \pm 14.1 \\
\text { (4) }\end{array}$ \\
\hline KA 30 & 4.3 & 41 & $1.1-22.4$ & $\begin{array}{c}5.9 \pm 1.3 \\
(65)\end{array}$ & $\begin{array}{c}10.2 \pm 2.3 \\
(35)\end{array}$ & \\
\hline KAR13 & 5.2 & 16 & $5.8-16.8$ & $\begin{array}{c}7.1 \pm 1.7 \\
(76)\end{array}$ & $\begin{array}{c}14.4 \pm 4.5 \\
(24)\end{array}$ & \\
\hline KAR12 & 6.0 & 44 & $3.2-28.2$ & $\begin{array}{c}7.9 \pm 1.3 \\
(79)\end{array}$ & $\begin{array}{c}13.3 \pm 6.0 \\
\quad(21)\end{array}$ & \\
\hline KA 34 & 6.4 & 63 & $1.1-25.7$ & $\begin{array}{c}3.6 \pm 2.2 \\
(9)\end{array}$ & $\begin{array}{c}9.6 \pm 1.7 \\
(81)\end{array}$ & $\begin{array}{c}13.9 \pm 19.5 \\
(10)\end{array}$ \\
\hline KAR10 & 8.1 & 59 & $2.7-34.3$ & $\begin{array}{c}6.5 \pm 0.8 \\
(98)\end{array}$ & $\begin{array}{c}23.8 \pm 29.0 \\
\text { (3) }\end{array}$ & \\
\hline KAR9 & 9.0 & 49 & $3.8-49.4$ & $\begin{array}{c}9.9 \pm 1.0 \\
(97)\end{array}$ & $\begin{array}{c}21.6 \pm 36.8 \\
\text { (3) }\end{array}$ & \\
\hline KAR7 & 10.9 & 56 & $1.4-31.6$ & $\begin{array}{c}5.1 \pm 2.6 \\
\quad(20)\end{array}$ & $\begin{array}{c}9.3 \pm 1.3 \\
(80)\end{array}$ & \\
\hline KAR6 & 12.1 & 48 & $0.9-26.0$ & $\begin{array}{c}2.1 \pm 1.8 \\
\quad(13)\end{array}$ & $\begin{array}{c}9.0 \pm 1.3 \\
(87)\end{array}$ & \\
\hline KAR3 & 14.1 & 51 & $0.4-22.3$ & $\begin{array}{c}1.8 \pm 1.3 \\
(43)\end{array}$ & $\begin{array}{c}5.2 \pm 1.8 \\
(54)\end{array}$ & $\begin{array}{c}17.2 \pm 24.2 \\
\text { (3) }\end{array}$ \\
\hline KA 441 & 15.9 & 44 & $1.2-22.0$ & $\begin{array}{c}2.4 \pm 0.4 \\
(82)\end{array}$ & $\begin{array}{c}11.8 \pm 2.0 \\
(18)\end{array}$ & \\
\hline KAR1 & 15.9 & 37 & $0.3-60.5$ & $\begin{array}{c}1.7 \pm 0.8 \\
(58)\end{array}$ & $\begin{array}{c}11.0 \pm 6.9 \\
(38)\end{array}$ & $\begin{array}{c}25.8 \pm 71.8 \\
\text { (4) }\end{array}$ \\
\hline KA441+KAR1 & 15.9 & 81 & $0.3-60.5$ & $\begin{array}{c}2.4 \pm 0.4 \\
(75)\end{array}$ & $\begin{array}{c}12.0 \pm 2.1 \\
(23)\end{array}$ & $\begin{array}{c}19.2 \pm 57.5 \\
\text { (2) }\end{array}$ \\
\hline \multicolumn{7}{|c|}{ Tinau Khola Section } \\
\hline TIN8 & 7.2 & 54 & $4.3-38.2$ & $\begin{array}{c}10.5 \pm 1.8 \\
(92)\end{array}$ & $\begin{array}{c}19.3 \pm 9.5 \\
(8)\end{array}$ & \\
\hline BUT4 & 9.1 & 29 & $2.2-16.2$ & $\begin{array}{c}2.3 \pm 1.2 \\
(6)\end{array}$ & $\begin{array}{c}7.0 \pm 0.7 \\
(94)\end{array}$ & \\
\hline BUT3 & 10.3 & 29 & $1.7-36.7$ & $\begin{array}{c}5.5 \pm 0.6 \\
(96)\end{array}$ & & $\begin{array}{c}34.9 \pm 31.5 \\
\text { (4) }\end{array}$ \\
\hline BUT3+TIN5 & 10.3 & 77 & $1.7-37.9$ & $\begin{array}{c}3.4 \pm 1.2 \\
(32)\end{array}$ & $\begin{array}{c}6.9 \pm 1.2 \\
(67)\end{array}$ & $\begin{array}{c}32.3 \pm 32.3 \\
\text { (2) }\end{array}$ \\
\hline TA18A & 11.0 & 39 & $0.5-18.2$ & $\begin{array}{c}6.3 \pm 1.5 \\
(92)\end{array}$ & $\begin{array}{c}14.7 \pm 6.3 \\
(8)\end{array}$ & \\
\hline TA17 & 11.3 & 34 & $1.6-24.5$ & $\begin{array}{c}5.4 \pm 1.2 \\
(83)\end{array}$ & $\begin{array}{c}9.0 \pm 5.9 \\
(17)\end{array}$ & \\
\hline BUT1 & 12.0 & 9 & $2.2-16.2$ & $\begin{array}{c}3.5 \pm 1.1 \\
(88)\end{array}$ & $\begin{array}{c}13.4 \pm 21.5 \\
(12)\end{array}$ & \\
\hline BUT1+TIN1 & 12.0 & 33 & $2.2-42.7$ & $\begin{array}{c}2.5 \pm 0.7 \\
(13)\end{array}$ & $\begin{array}{c}6.9 \pm 2.0 \\
(83)\end{array}$ & $\begin{array}{c}31.6 \pm 29.7 \\
(4)\end{array}$ \\
\hline
\end{tabular}

$\mathrm{N}=$ number of grains counted; fitted binomial peak ages $(\mathrm{P} 1-\mathrm{P} 3)$ are given $\pm 2 \sigma(95 \%$ confidence interval). Numbers in parentheses correspond to the percentage of grains in a given peak. 
Table 3. Track-length and etch-pit width measurements.

\begin{tabular}{cccccc}
\hline Sample & $\begin{array}{c}\text { MTL } \pm \mathbf{1 \sigma} \\
(\mu \mathrm{m})\end{array}$ & $\begin{array}{c}\text { st. dev. } \\
(\mu \mathrm{m})\end{array}$ & $\mathbf{N}$ & $\begin{array}{c}\mathbf{D}_{\text {par }} \\
(\mu \mathrm{m})\end{array}$ & $\begin{array}{c}\text { st. dev. } \\
(\mu \mathrm{m})\end{array}$ \\
\hline \multicolumn{2}{c}{ Karnali Section } \\
KAR14 & $11.7 \pm 0.3$ & 2.0 & 84 & 1.7 & 0.4 \\
KAR13 & & & & 1.7 & 0.3 \\
KAR12 & $11.0 \pm 0.3$ & 2.9 & 75 & 1.6 & 0.3 \\
KAR11 & $11.3 \pm 0.3$ & 2.6 & 78 & 1.6 & 0.3 \\
KAR10 & $12.1 \pm 0.2$ & 2.0 & 68 & 1.8 & 0.3 \\
KAR9 & $11.2 \pm 0.3$ & 2.5 & 54 & 1.3 & 0.4 \\
KAR7 & $10.7 \pm 0.2$ & 2.1 & 80 & 1.6 & 0.4 \\
KAR6 & $9.4 \pm 0.3$ & 1.9 & 51 & 1.2 & 0.3 \\
KAR3 & $9.5 \pm 0.3$ & 1.9 & 36 & 1.5 & 0.4
\end{tabular}

\section{Tinau Khola Section}

TIN8 $\quad 10.9 \pm 0.2 \quad 1.6 \quad 100$

Track lengths and etch-pit widths were measured by X. Robert. Samples were ${ }^{252} \mathrm{Cf}$-irradiated before revealing confined horizontal tracks. $\mathrm{MTL}=$ mean track length; $\mathrm{N}=$ number of horizontal confined tracks measured. $\mathrm{D}_{\text {par }}=$ etch-pit width parallel to the $\mathrm{C}$ axis. 100 etch-pit widths were measured for each sample.

Table 4. Results of binomial peak-age fitting for Bengal Fan data

\begin{tabular}{|c|c|c|c|c|c|}
\hline Sample & $\begin{array}{c}\text { Strat. age } \\
(\mathrm{Ma})\end{array}$ & $\mathbf{N}$ & $\begin{array}{c}\text { Age range } \\
(\mathrm{Ma})\end{array}$ & $\begin{array}{c}\mathbf{P} 1 \pm 2 \sigma \\
(\mathrm{Ma})\end{array}$ & $\begin{array}{c}\mathbf{P} 2 \pm 2 \sigma \\
(\mathrm{Ma})\end{array}$ \\
\hline \multicolumn{6}{|l|}{ Site 717} \\
\hline 7-0 & $0.3 \pm 0.3$ & 30 & $1.0-25.7$ & $\begin{array}{l}4.4 \pm 1.3 \\
\quad(95)\end{array}$ & $\begin{array}{c}20.8 \pm 26.9 \\
(5)\end{array}$ \\
\hline $7-220$ & $3.0 \pm 0.8$ & 30 & $1.5-17.0$ & $\begin{array}{c}6.6 \pm 1.8 \\
(100)\end{array}$ & \\
\hline $7-420$ & $6.0 \pm 0.4$ & 30 & $1.8-21.3$ & $\begin{array}{c}7.7 \pm 3.8 \\
(65)\end{array}$ & $\begin{array}{c}11.6 \pm 8.3 \\
(35)\end{array}$ \\
\hline $7-620$ & $8.0 \pm 0.5$ & 30 & $2.9-22.1$ & $\begin{array}{c}11.9 \pm 2.4 \\
(100)\end{array}$ & \\
\hline $7-720$ & $9.0 \pm 0.5$ & 30 & $9.1-37.5$ & $\begin{array}{c}14.3 \pm 2.8 \\
(100)\end{array}$ & \\
\hline \multicolumn{6}{|l|}{ Site 718} \\
\hline 8-290 & $9.0 \pm 0.7$ & 30 & $5.7-30.2$ & $\begin{array}{c}14.3 \pm 3.1 \\
(84)\end{array}$ & $\begin{array}{c}25.5 \pm 11.9 \\
(16)\end{array}$ \\
\hline $8-460$ & $10.6 \pm 0.3$ & 30 & $8.1-190.3$ & $\begin{array}{c}18.9 \pm 3.4 \\
(97)\end{array}$ & $\begin{array}{c}190.3 \pm 82.8 \\
\text { (3) }\end{array}$ \\
\hline $8-660$ & $14.4 \pm 1.4$ & 30 & $5.8-82.4$ & $\begin{array}{c}16.2 \pm 6.8 \\
(54)\end{array}$ & $\begin{array}{c}21.4 \pm 9.9 \\
(46)\end{array}$ \\
\hline $8-760$ & $16.3 \pm 0.6$ & 30 & $10.2-32.8$ & $\begin{array}{c}18.0 \pm 3.6 \\
\quad(100)\end{array}$ & \\
\hline $8-860$ & $17.0 \pm 0.2$ & 30 & $7.7-25.7$ & $\begin{array}{c}15.8 \pm 3.0 \\
(100)\end{array}$ & \\
\hline
\end{tabular}

Data from Corrigan and Crowley (1990). Notations as in Table 2. 

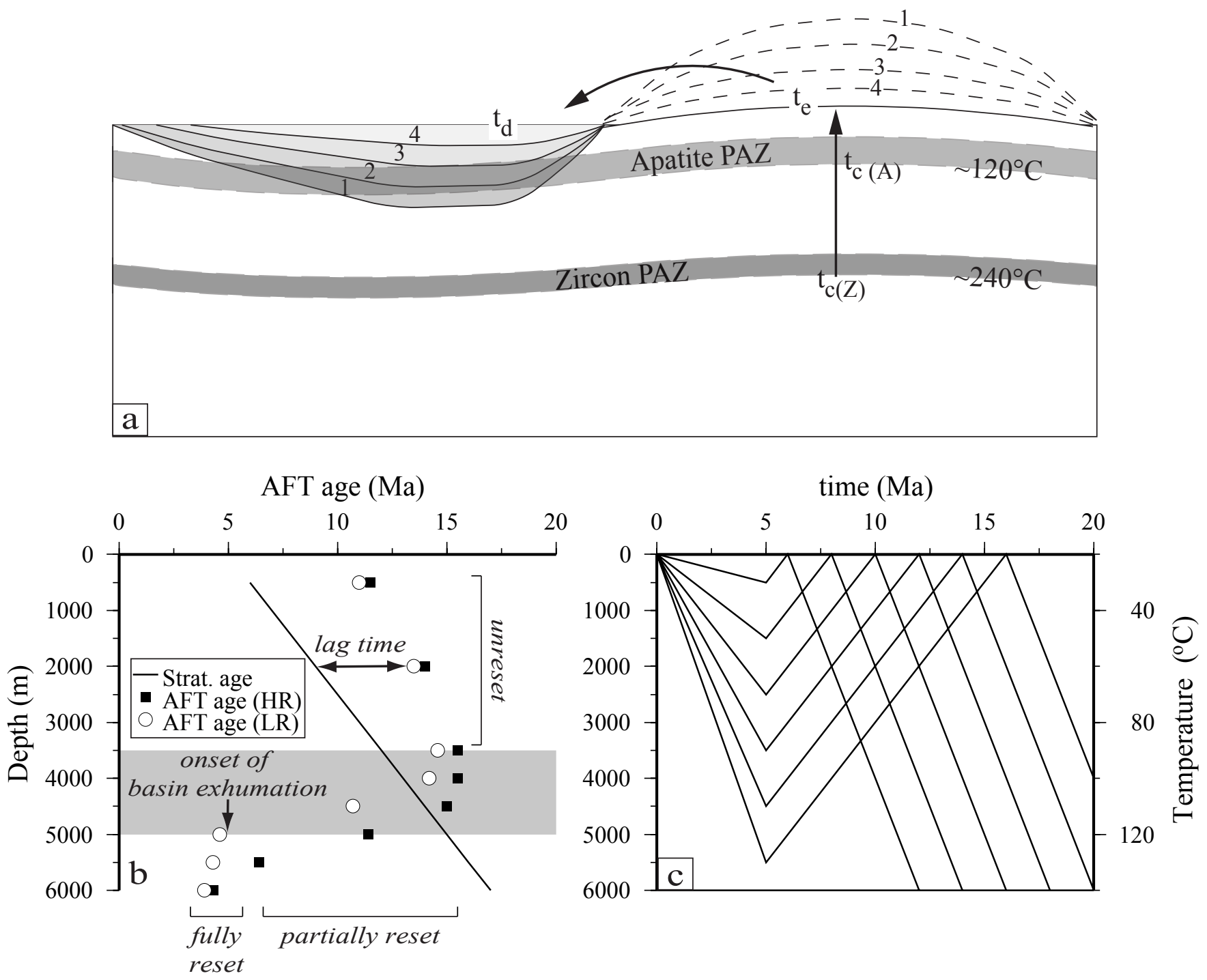

van der Beek et al.,

Figure 1 


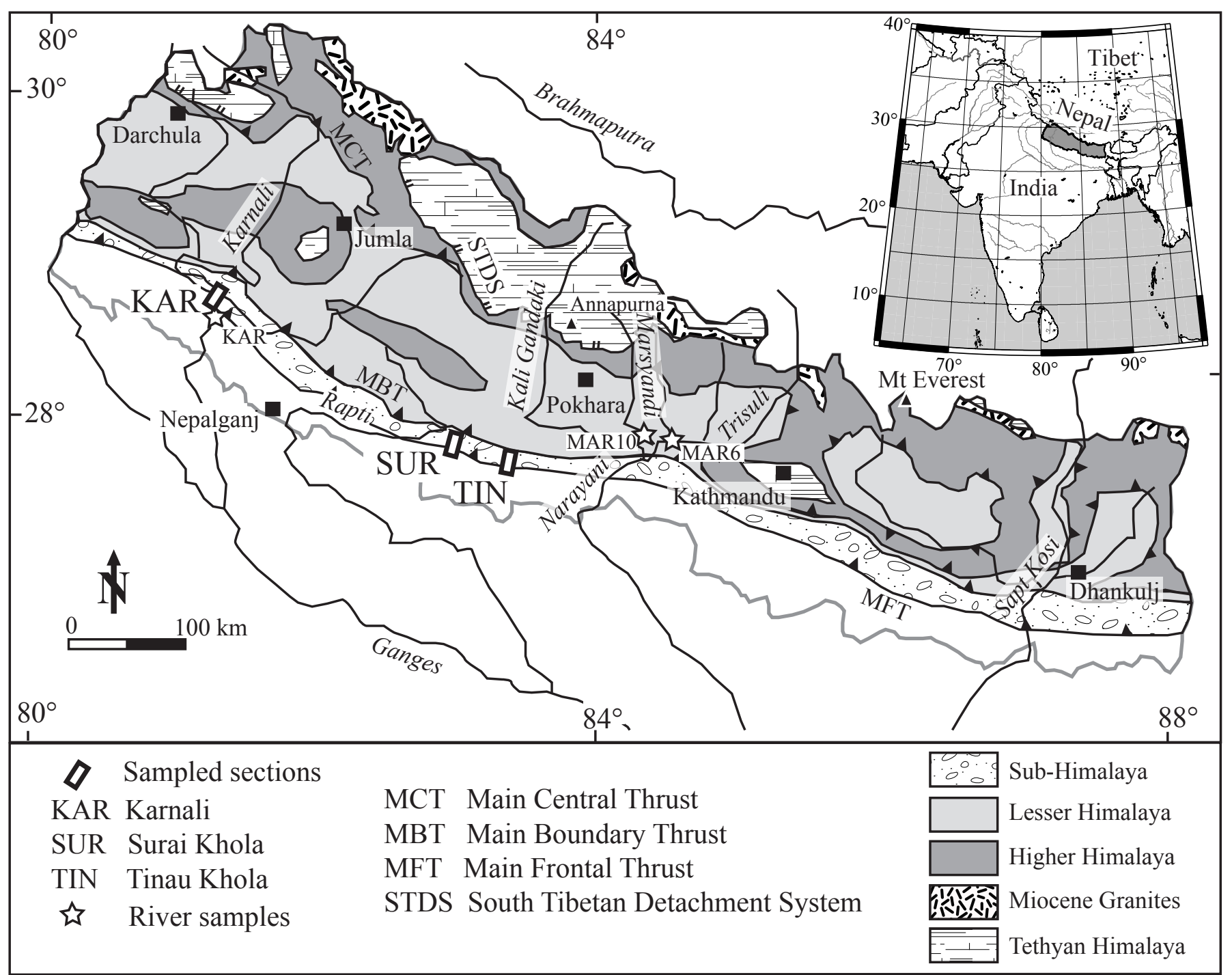

van der Beek et al.

Figure 2 


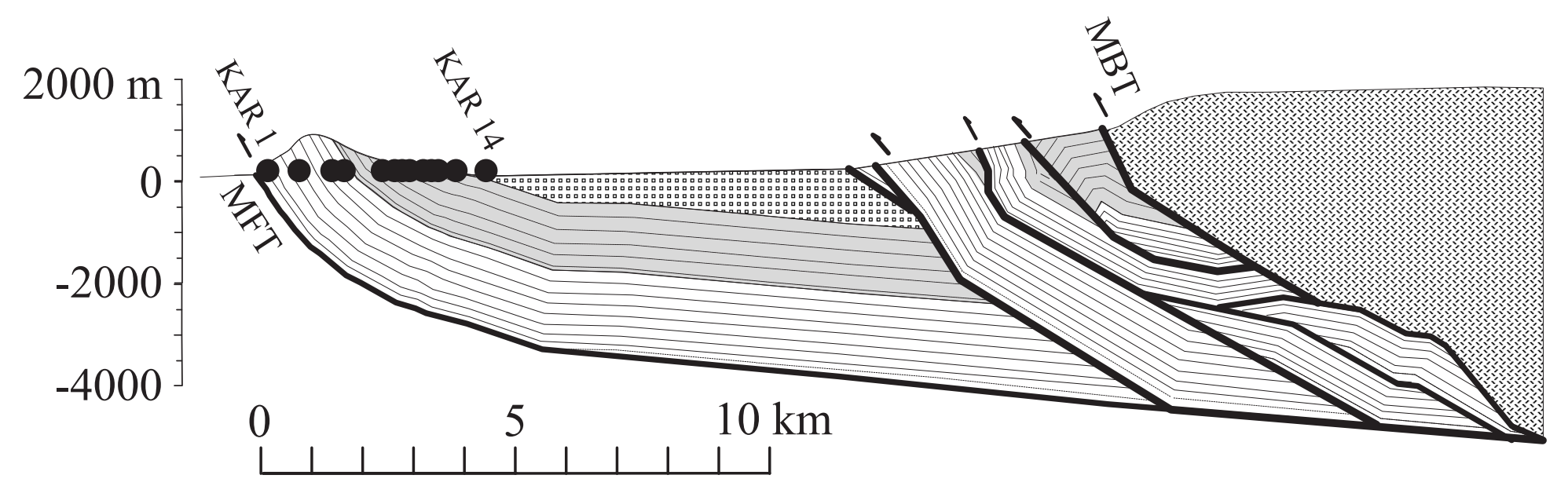

Upper Siwaliks

Middle Siwaliks

Lower Siwaliks

Lesser Himalayas

van der Beek et al.

Figure 3 


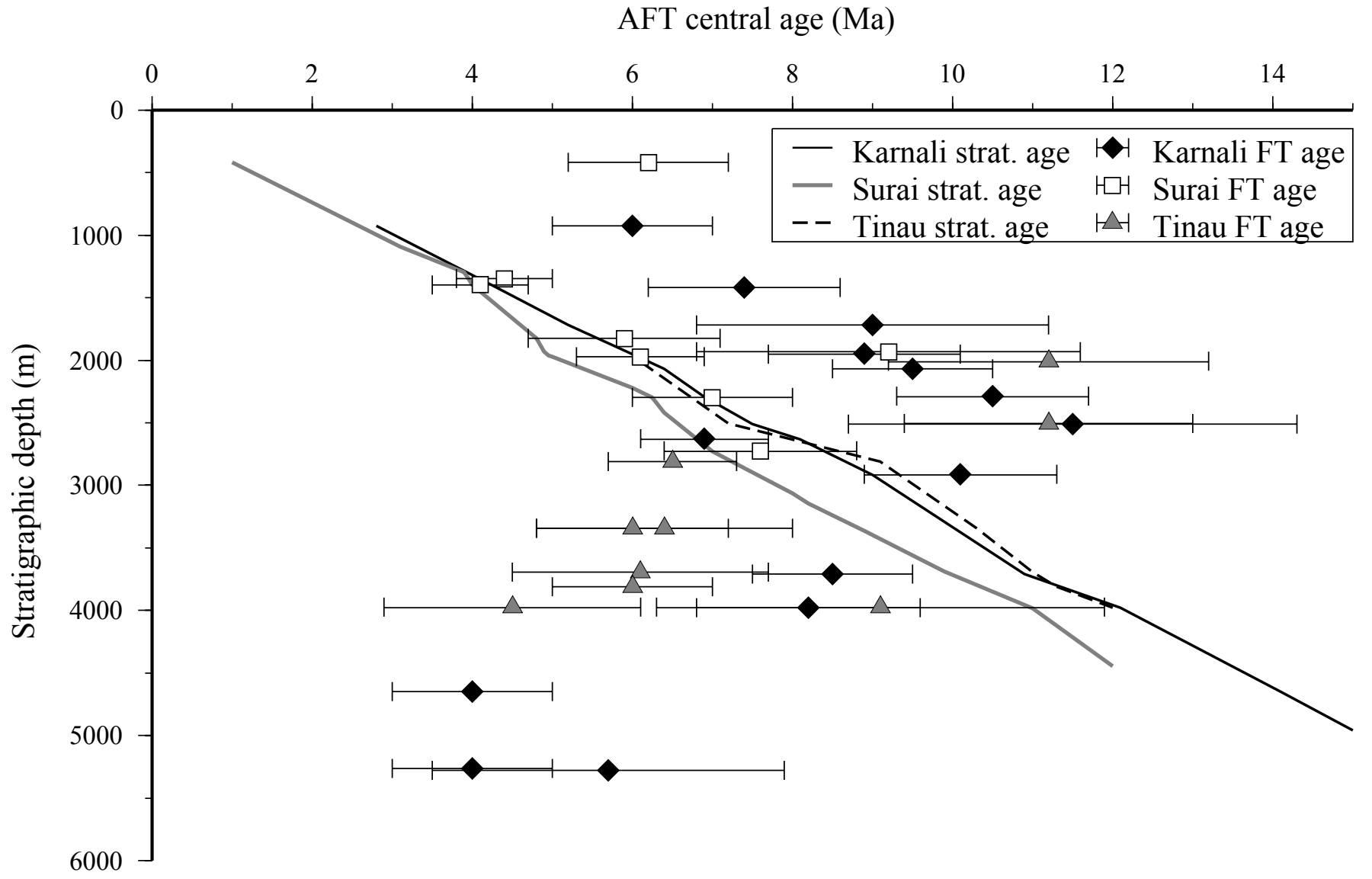

van der Beek et al.,

Figure 4 

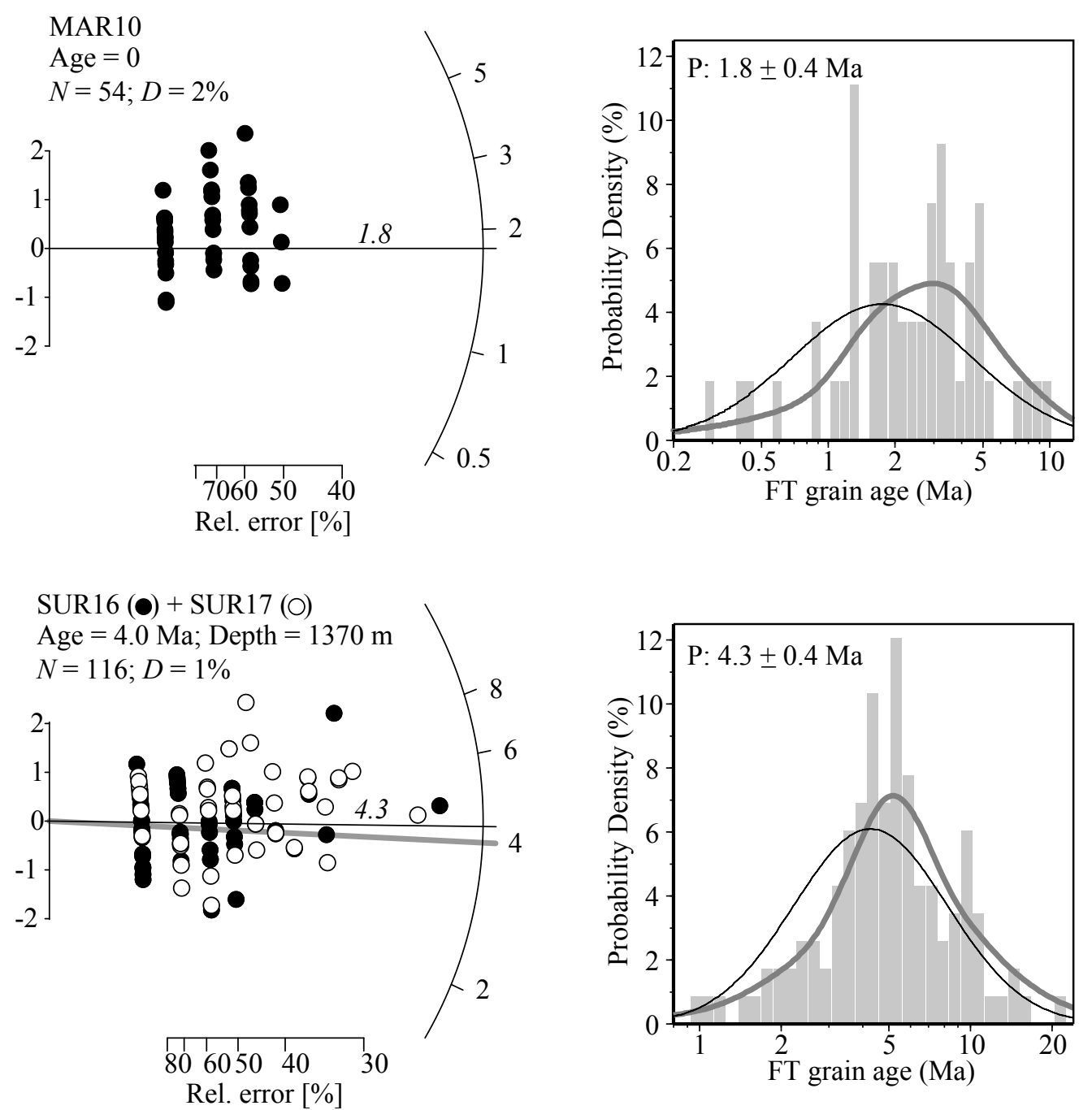

\section{SUR 8}
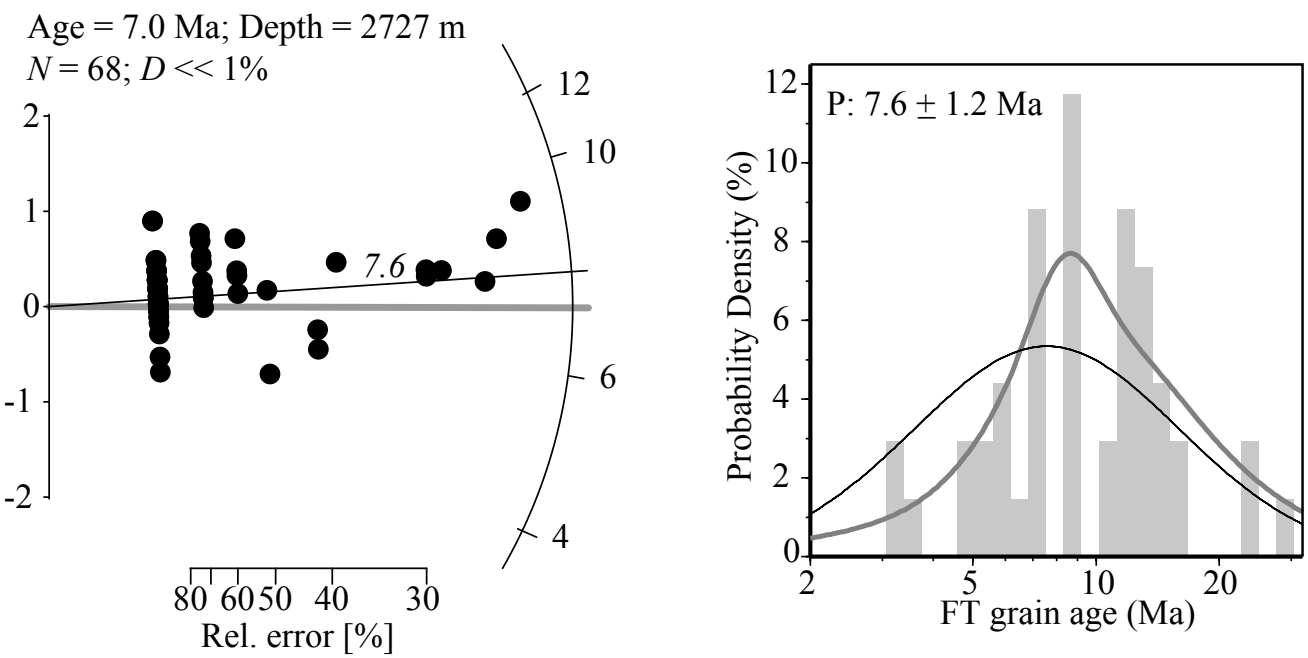

van der Beek et al., Figure 5 

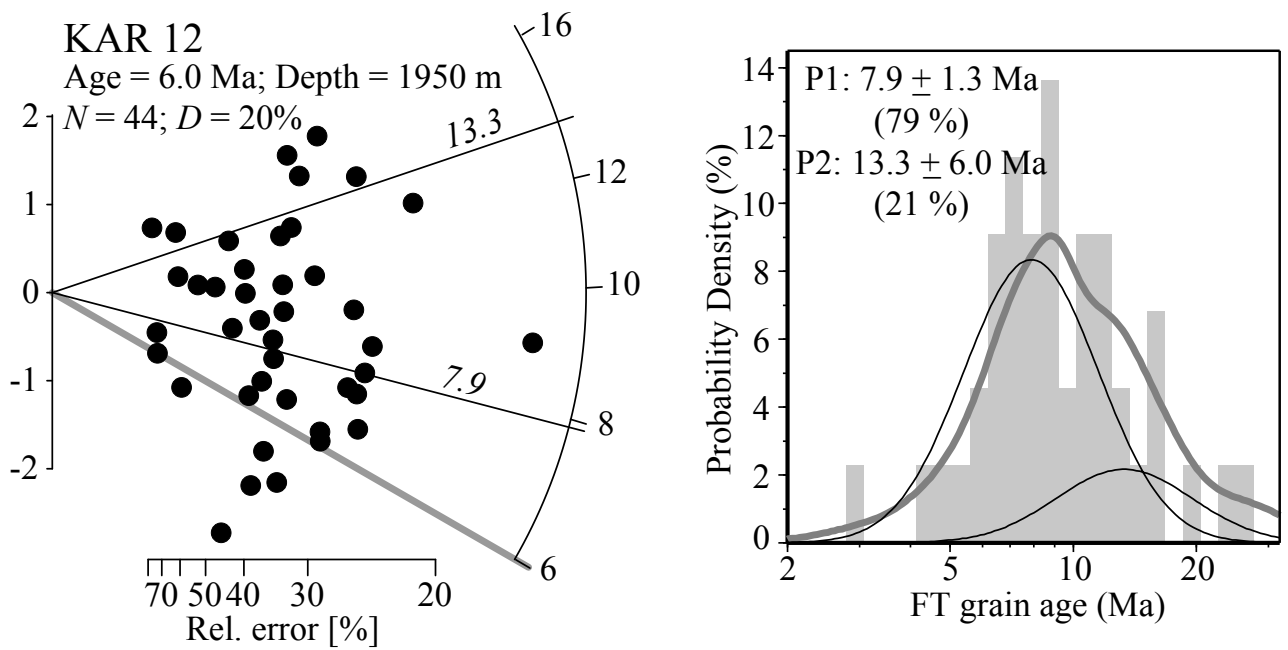

KAR 6

Age $=12.1 \mathrm{Ma} ;$ Depth $=3980 \mathrm{~m}$ $N=48 ; D=31 \%$
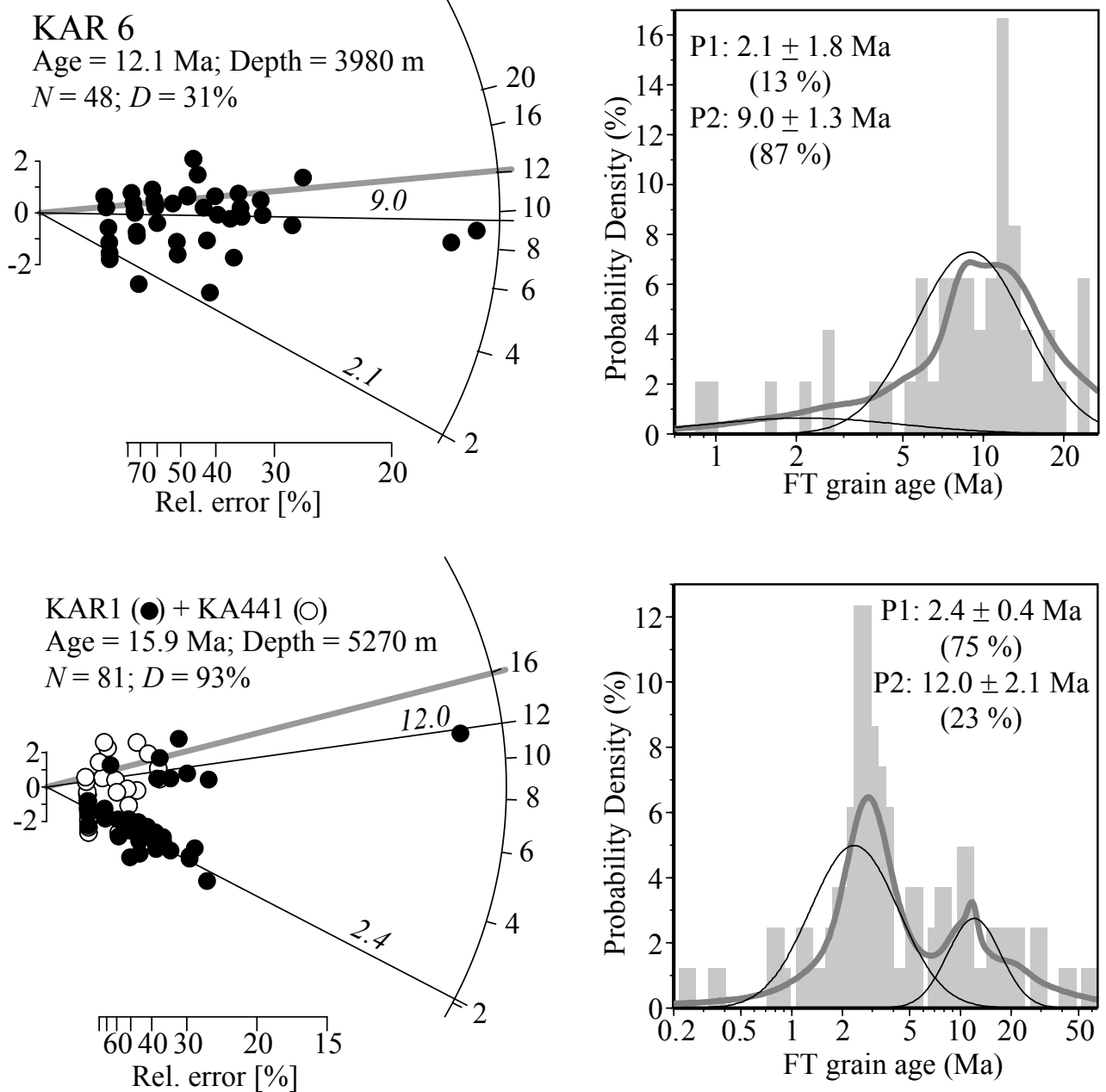

van der Beek et al., Figure 5 (cont) 


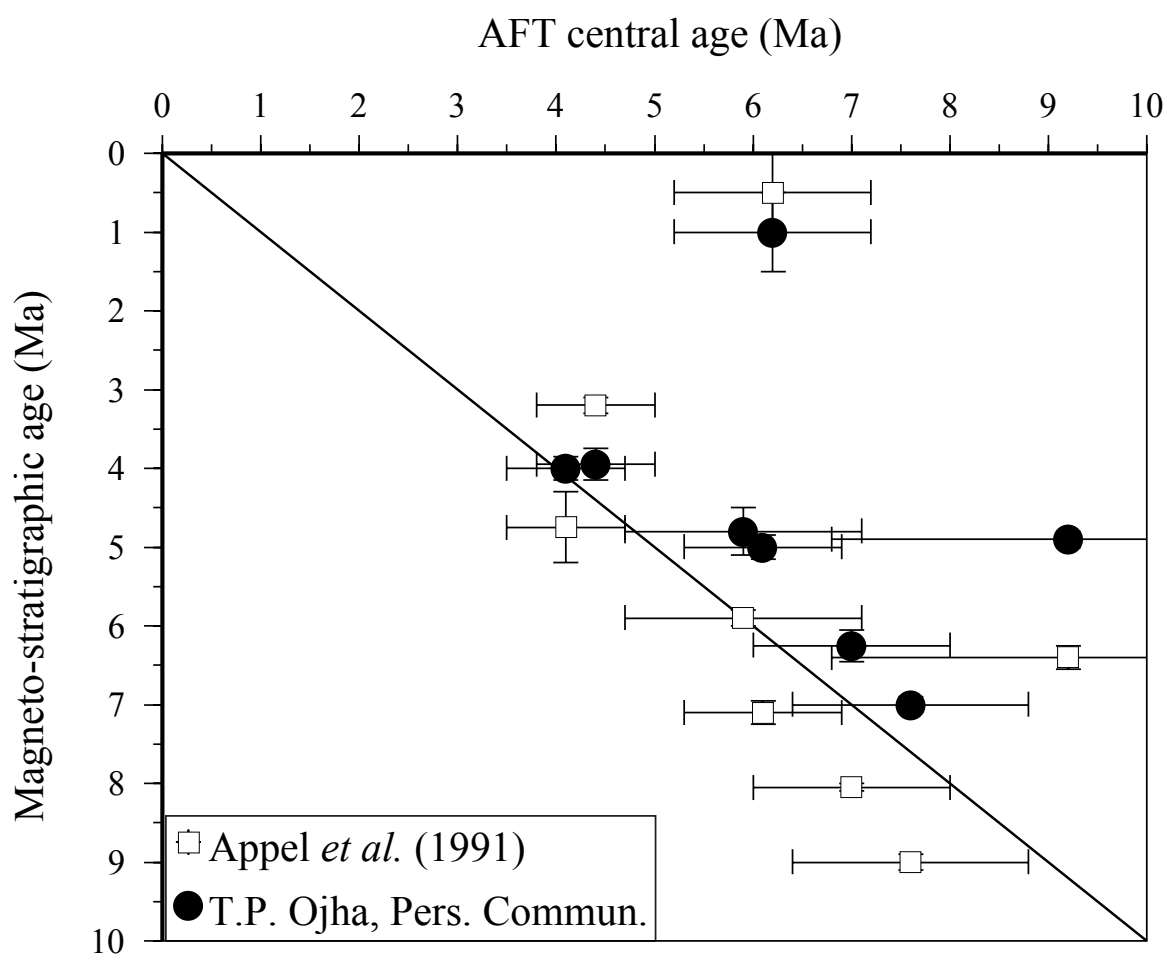

van der Beek et al.

Figure 6 


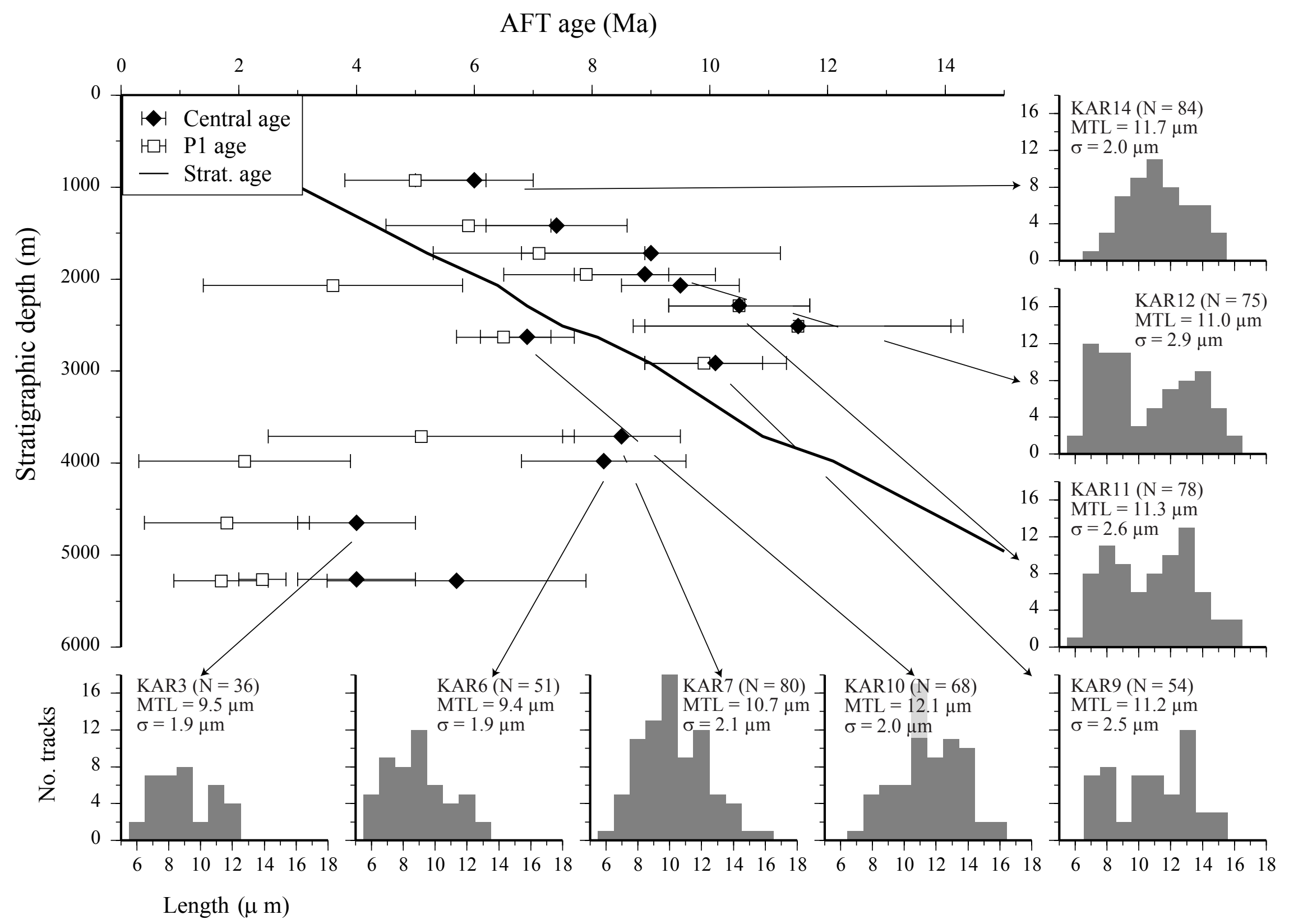

van der Beek et al., Figure 7 


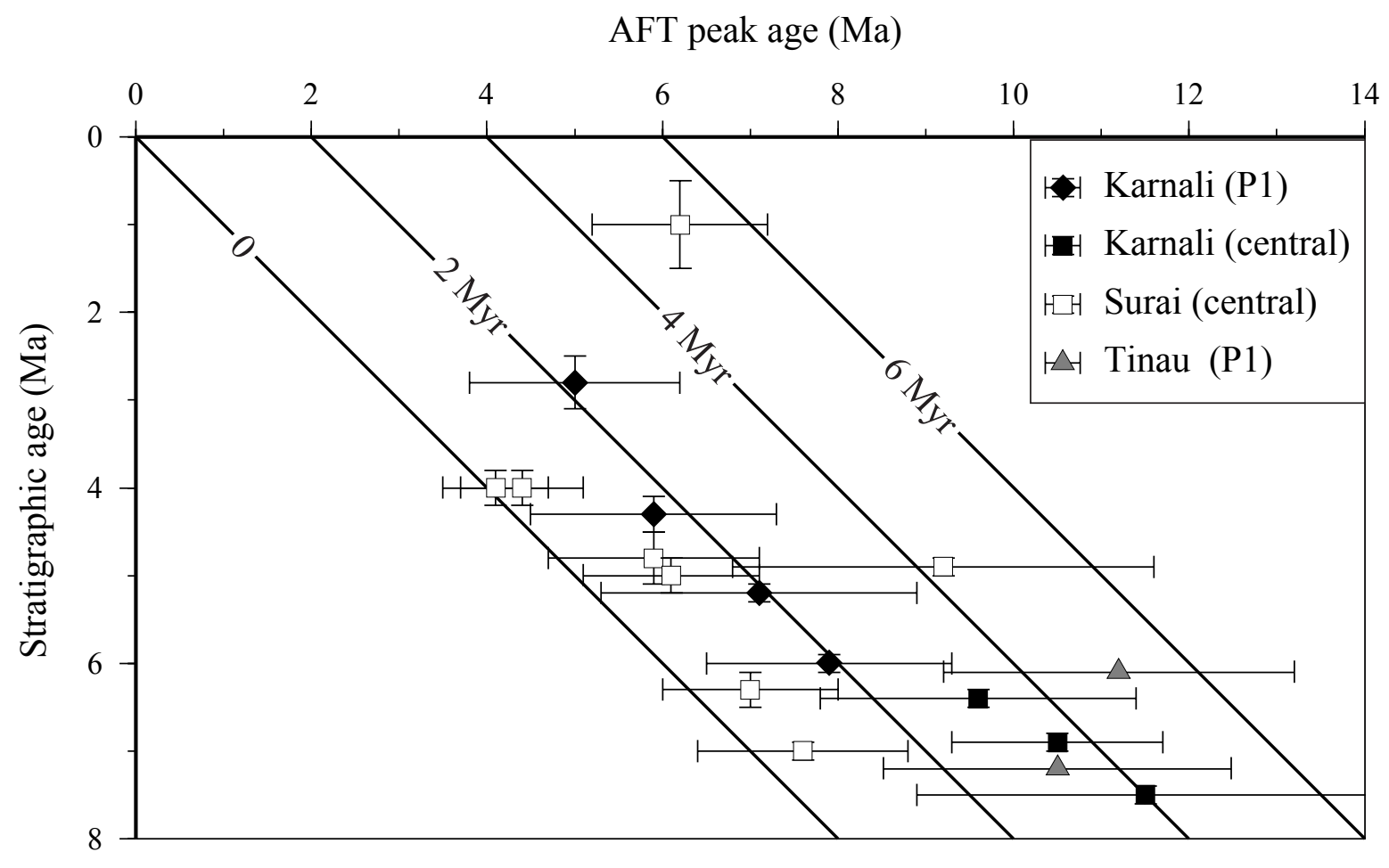

van der Beek et al.

Figure 8 

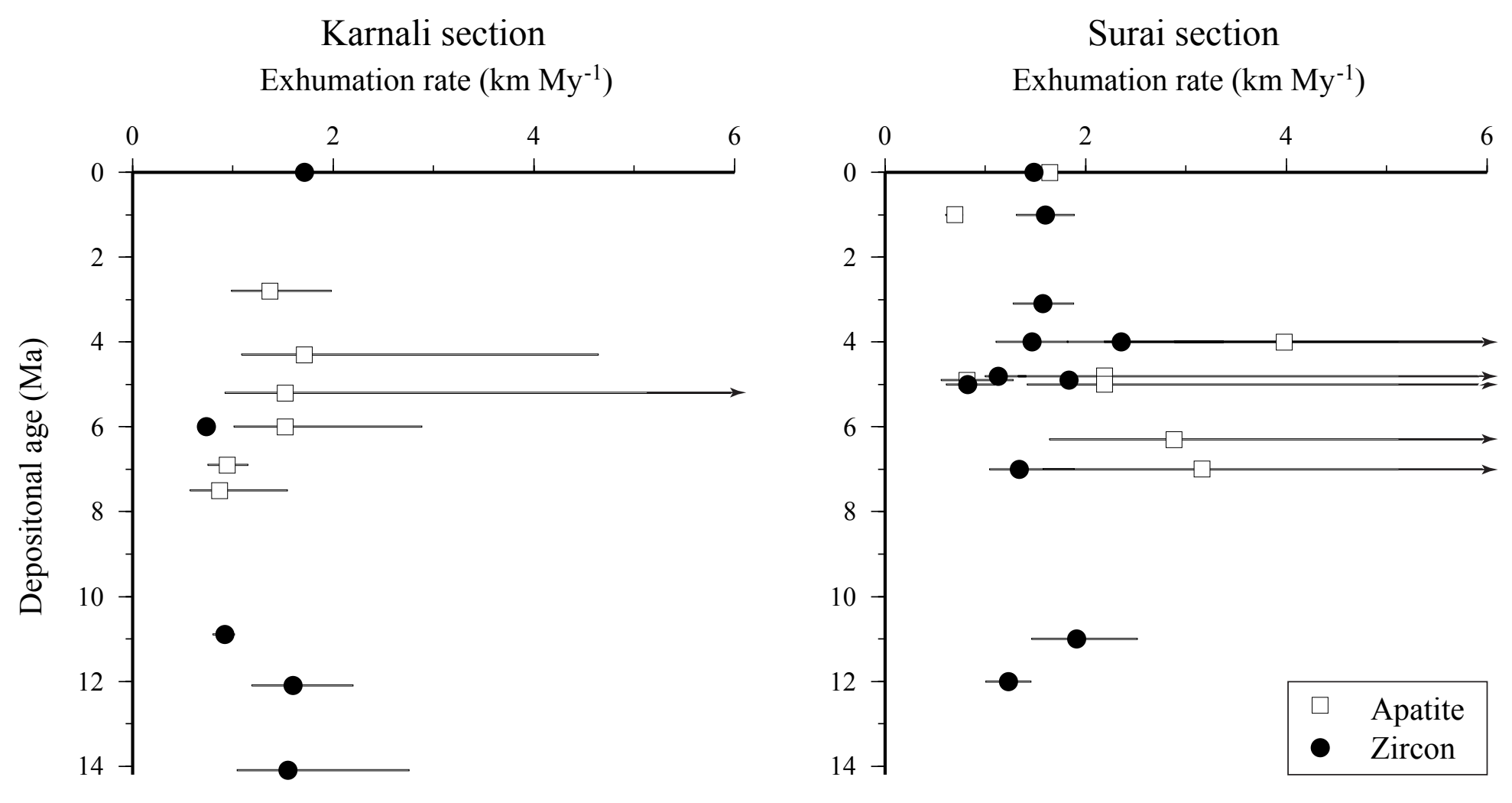

van der Beek et al., Figure 9 


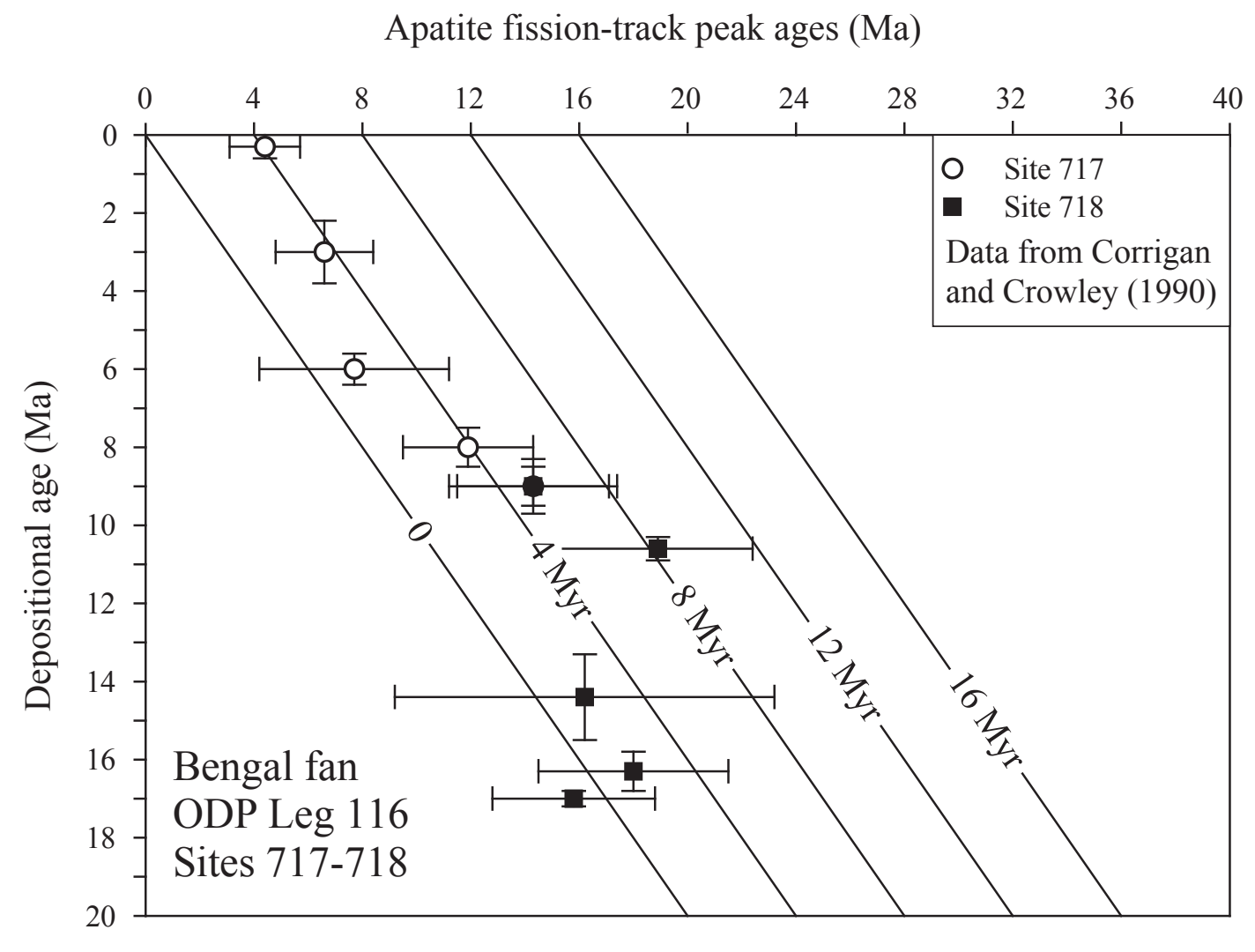

Figure 10 

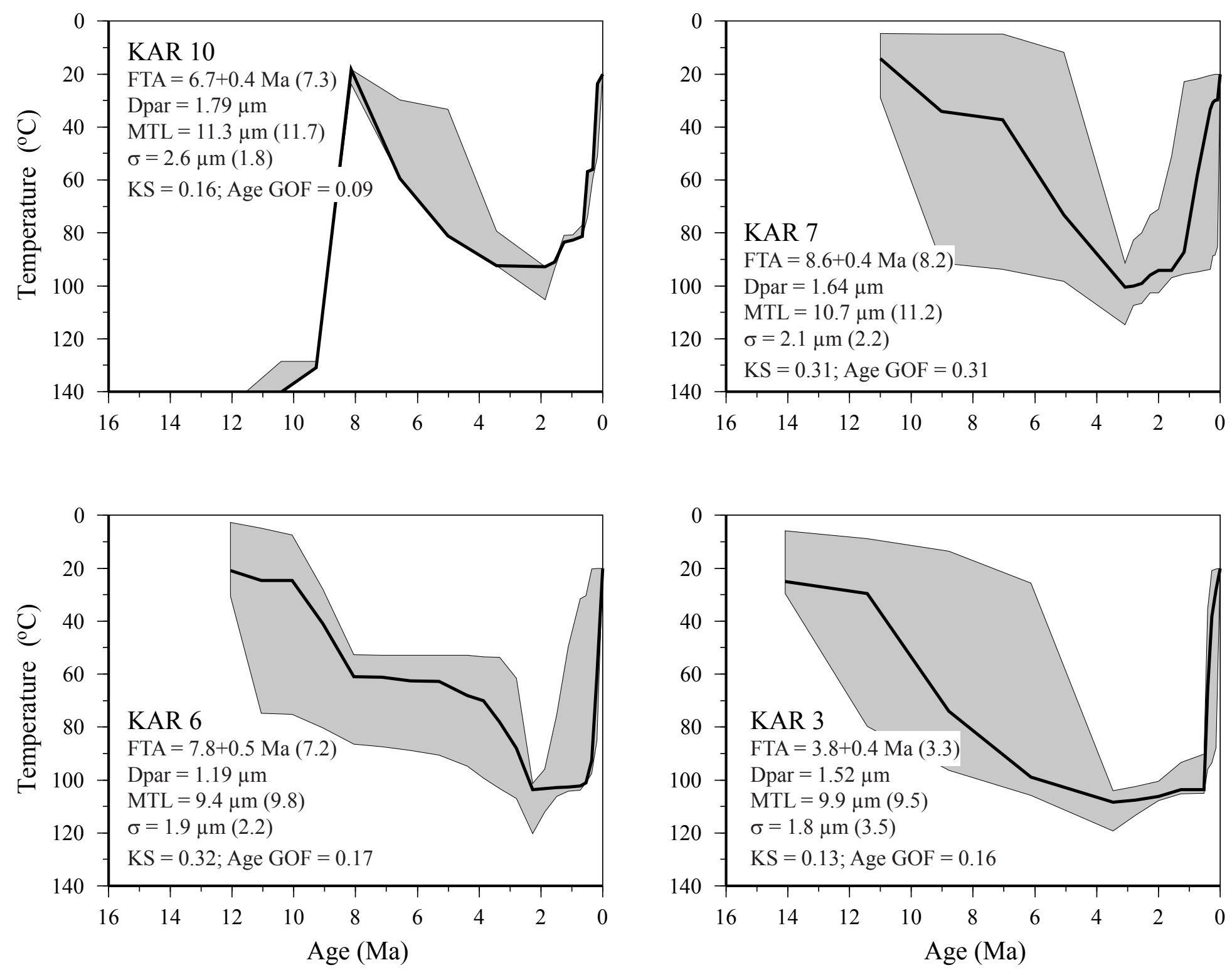

van der Beek et al., Figure 11 


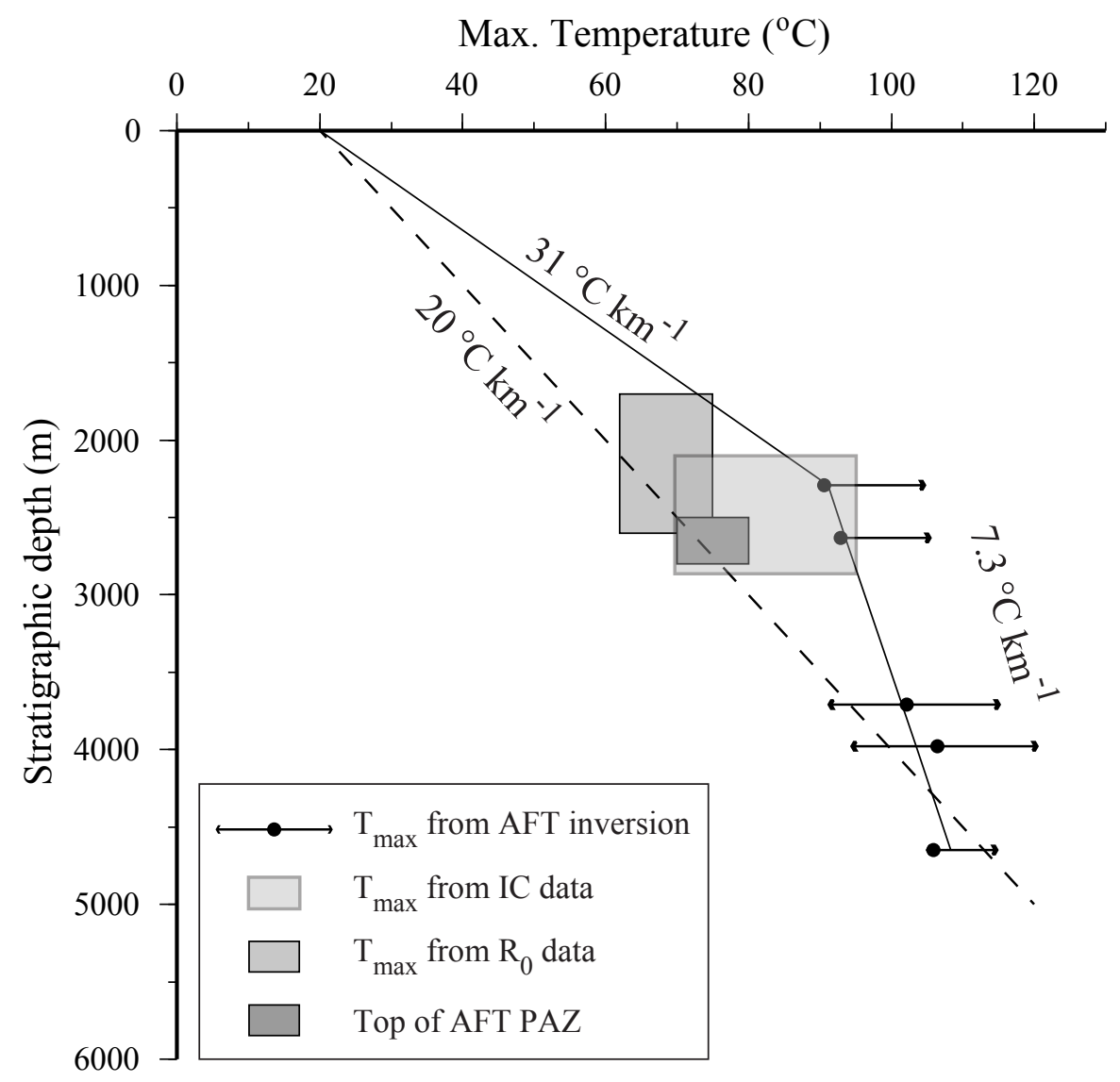

van der Beek et al.,

Figure 12 